Report of Investigations 2005-1

\title{
EXPLANATORY BOOKLET TO ACCOMPANY GEOLOGIC, BEDROCK, AND SURFICIAL MAPS OF THE BIG HURRAH AND COUNCIL AREAS, SEWARD PENINSULA, ALASKA
}

by

M.B. Werdon, D.S.P. Stevens, R.J. Newberry, D.J. Szumigala, J.E. Athey, and S.A. Hicks

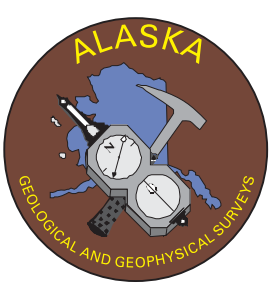

Published by

STATE OF ALASKA

DEPARTMENT OF NATURAL RESOURCES

DIVISION OF GEOLOGICAL \& GEOPHYSICAL SURVEYS 
Report of Investigations 2005-1

\title{
EXPLANATORY BOOKLET TO ACCOMPANY GEOLOGIC, BEDROCK, AND SURFICIAL MAPS OF THE BIG HURRAH AND COUNCIL AREAS, SEWARD PENINSULA, ALASKA
}

\author{
by
}
M.B. Werdon, D.S.P. Stevens, R.J. Newberry, D.J. Szumigala, J.E. Athey, and S.A. Hicks

2005

This DGGS Report of Investigations is a final report of scientific research. It has received technical review and may be cited as an agency publication. 


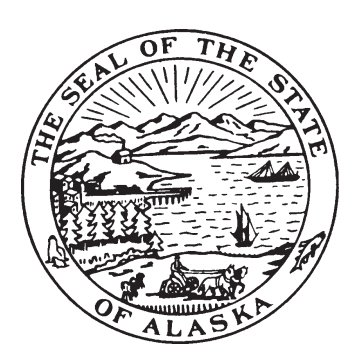

STATE OF ALASKA

Frank Murkowski, Governor

DEPARTMENT OF NATURAL RESOURCES

Tom Irwin, Commissioner

DIVISION OF GEOLOGICAL \& GEOPHYSICAL SURVEYS

Mark D. Myers, State Geologist and Director

Division of Geological \& Geophysical Surveys publications can be inspected at the following locations. Address mail orders to the Fairbanks office.
Alaska Division of Geological
\& Geophysical Surveys
3354 College Road
University of Alaska Anchorage Library
3211 Providence Drive
Anchorage, Alaska 99508

Fairbanks, Alaska 99709-3707

Elmer E. Rasmuson Library

University of Alaska Fairbanks

Alaska Resource Library

Fairbanks, Alaska 99775-1005

3150 C Street, Suite 100

Anchorage, Alaska 99503

Alaska State Library

State Office Building, 8th Floor

333 Willoughby Avenue

Juneau, Alaska 99811-0571

This publication released by the Division of Geological \& Geophysical Surveys was produced and printed in Fairbanks, Alaska at a cost of $\$ 2$ per copy. Publication is required by Alaska Statute 41, "to determine the potential of Alaskan land for production of metals, minerals, fuels, and geothermal resources; the location and supplies of groundwater and construction materials; the potential geologic hazards to buildings, roads, bridges, and other installations and structures; and shall conduct such other surveys and investigations as will advance knowledge of the geology of Alaska.” 


\section{CONTENTS}

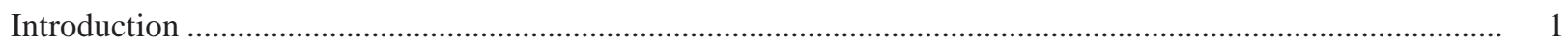

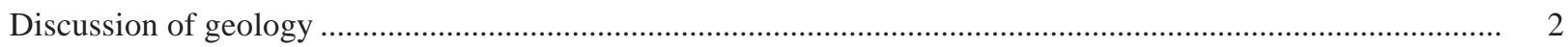

Nome Group metasedimentary and metaigneous rocks .......................................................................... 2

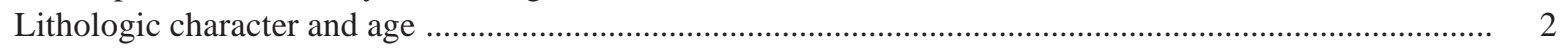

Relationships between Nome Group units ....................................................................................... 8

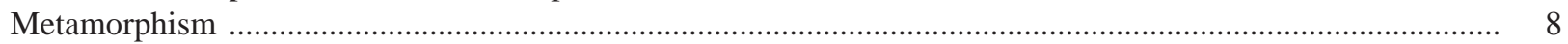

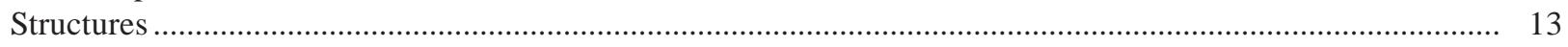

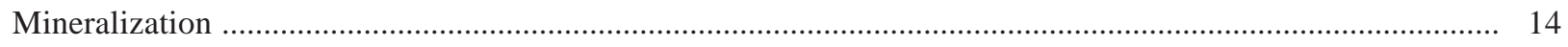

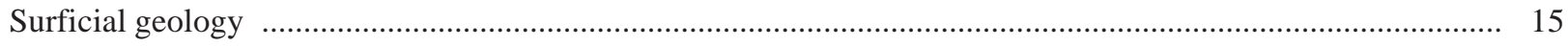

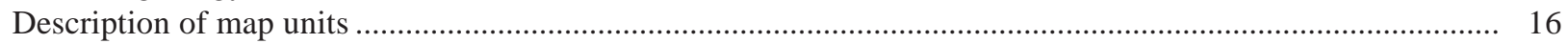

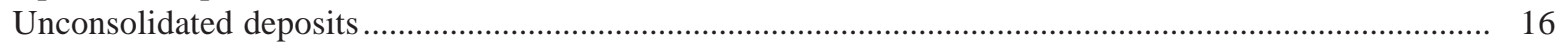

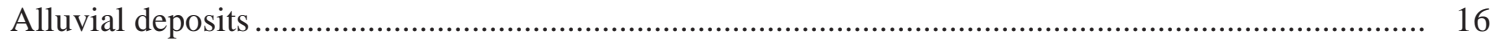

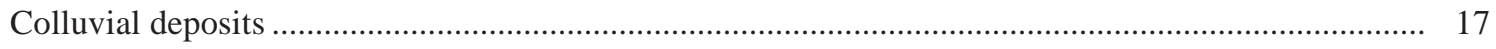

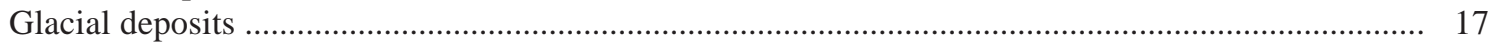

Nome River glaciation ............................................................................................................... 17

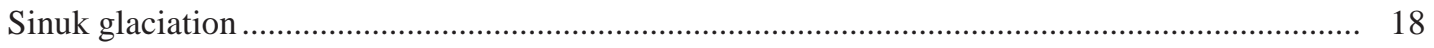

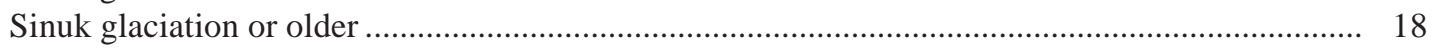

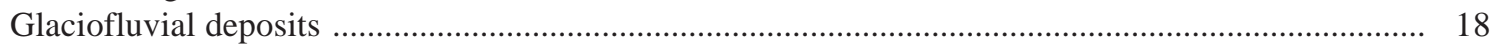

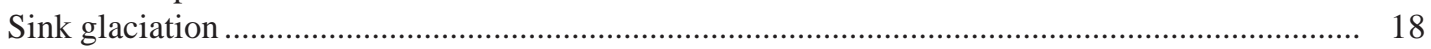

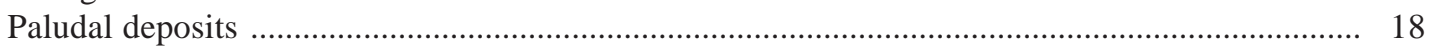

Complex units ................................................................................................................. 19

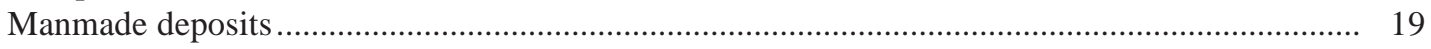

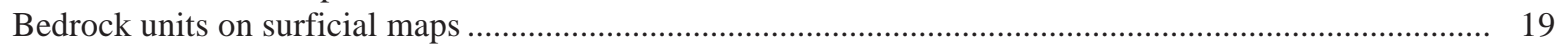

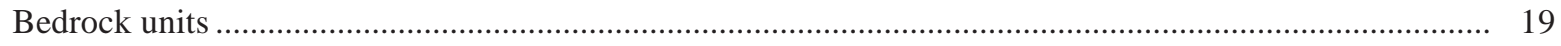

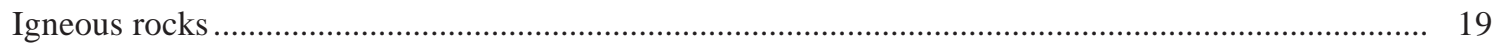

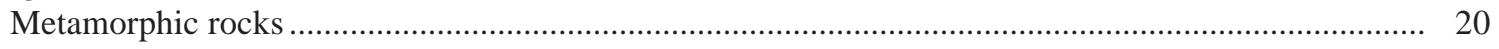

Sedimentary and igneous rocks metamorphosed to blueschist facies: Nome Group ..................... 20

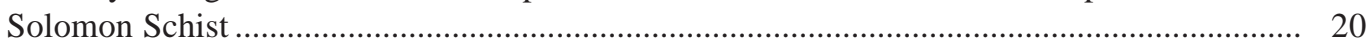

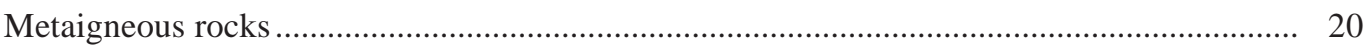

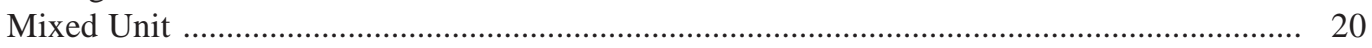

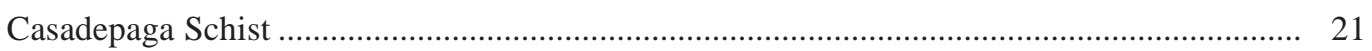

Undifferentiated Nome Group ........................................................................................ 23

Sedimentary and igneous rocks metamorphosed to amphibolite facies ........................................... 23

Acknowledgments

References cited

\section{TABLES}

Table 1. Rb-Sr data for whole rock samples of metabasite, metagraywacke, and mixed metasedimentary-metavolcanic rocks from the Casadepaga Schist, and marble from the Mixed Unit ............................................................................................. and D-5 quadrangles, Seward Peninsula, Alaska

\section{FIGURES}

Figure 1. Maps showing the location of the Big Hurrah and Council map areas ........................................... 1

2. Graphs showing Sr isotopic data for marble from Mixed Unit.......................................................... 3

3. Lithologic discrimination diagram for Casadepaga Schist ................................................................. 5

4. Metamorphosed mafic rocks from the Big Hurrah and Council map areas plotted 
on Ti-Zr-Y and Nb-Zr-Y tectonic discrimination diagrams for basalts

5. Rb-Sr isochron diagram for metabasite and metavolcanic rocks of the Casadepaga

Schist

6. Graph showing composition of 3,221 analyses of basalt relative to metabasite from unit DOg ........ 7

7. A. Graph showing ${ }^{40} \mathrm{Ar} /{ }^{39} \mathrm{Ar}$ step-heating fraction data for repeated runs of barroisite .................... 12

B. Graph showing microprobe analyses of barroisite .......................................................... 12

8. Lower-hemisphere, Schmidt equal-area stereonet plots of poles to foliation, and trend and plunge of isoclinal and non-isoclinal fold axes, for the Big Hurrah and Council map areas

9. Graph showing lead secondary isochron from gold-bearing quartz veins throughout the Seward Peninsula 


\title{
EXPLANATORY BOOKLET TO ACCOMPANY GEOLOGIC, BEDROCK, AND SURFICIAL MAPS OF THE BIG HURRAH AND COUNCIL AREAS, SEWARD PENINSULA, ALASKA
}

\author{
by
}

Melanie B. Werdon, ${ }^{1}$ De Anne S.P. Stevens, ${ }^{1}$ Rainer J. Newberry, ${ }^{2}$

David J. Szumigala, ${ }^{1}$ Jennifer E. Athey, ${ }^{1}$ and Shelley A. Hicks ${ }^{2}$

\section{INTRODUCTION}

Report of Investigations 2005-1 contains three maps (geologic, bedrock, and surficial) for each of two separate areas in southern Seward Peninsula, Alaska. Maps 1a-1c cover the area surrounding the historic Big Hurrah lode gold mine in the Solomon C-5 Quadrangle. Maps 1d-1f cover portions of the Solomon D-4 and Bendeleben A-4 quadrangles, and contain the historic Ophir Creek placer gold-bearing region near the town of Council (fig. 1). The two 1:50,000-scale map sets cover a 284-square-mile area that corresponds with portions the Council airborne geophysical survey released by the Alaska Division of Geological \& Geophysical Surveys (DGGS) in 2003 (Burns and others, 2003). The geophysical survey and these geologic maps are part of the State's Alaska Airborne Geophysical/ Geological Mineral Inventory program centered around established mining districts. Approximately 27,000 ounces of gold were produced from low-sulfide, gold-bearing quartz veins at the Big Hurrah mine between 1903 and 1907 (Read and Meinert, 1986), and the mine is currently the focus of renewed industry evaluation. More than 1 million ounces of placer gold have been extracted from the SolomonCouncil area since the turn of the century, with most production derived from the Casadepaga and Solomon rivers, and the Ophir Creek drainage. The northeastern portion of the airborne geophysical survey is also the focus of an ongoing NASA-funded remote-sensing project (through DGGS) to evaluate the area's potential for additional reserves of placer gold. A preliminary geologic map was published by DGGS in 1994 (Bundtzen and others, 1994) of the Nome geophysical survey area (fig. 1; Burns and others, 2005), and a final version of the Nome geologic map is in preparation by Bundtzen and others.

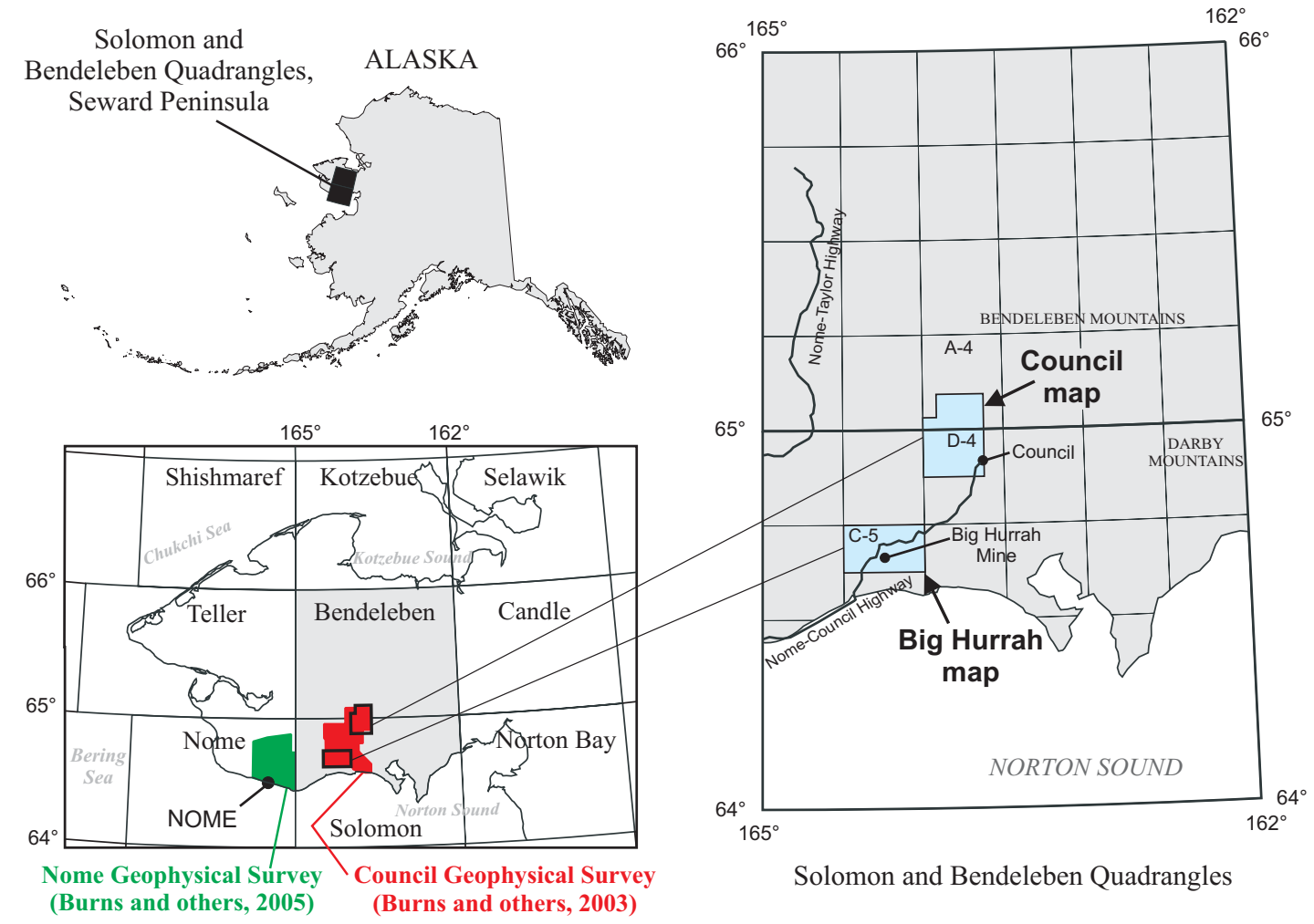

Figure 1. Maps showing the location of the Big Hurrah and Council map areas (shown in blue; this study), and DGGS's Council (shown in red) and Nome (shown in green) airborne geophysical surveys.

\footnotetext{
${ }^{1}$ Alaska Division of Geological \& Geophysical Surveys, 3354 College Rd., Fairbanks, Alaska 99709-3707

${ }^{2}$ Department of Geology and Geophysics, University of Alaska, PO Box 755780, Fairbanks, Alaksa 99775-5780
} 
Bedrock geologic maps were produced from 195 person days of field work conducted during August 2003, and the months of June through August, 2004, by geologists from DGGS and the University of Alaska Fairbanks. During the field portion of this study, we collected field notes and rock samples at approximately 3,460 stations throughout the two map areas, and adjacent portions of the Solomon and Bendeleben quadrangles. Airborne geophysical data sets were used to locate geophysically inferred faults and unit boundaries, identify unusual anomalies for follow-up investigation, and extend mapped contacts through regions covered by vegetation or surficial deposits. Map unit descriptions are based on field observations and further analytical work, including petrographic study and modal analysis of more than 500 thin sections. Approximately 100 rocks were analyzed for major- and minor-oxides and trace elements (Werdon and others, 2005). These data are used to determine permissible protoliths for metamorphic rocks, and to assign root names and trace-element-indicated tectonic settings to igneous and metamorphosed igneous rocks according to established petrologic nomenclature. Supplemental data obtained as part of this study include detrital zircon analysis of the Solomon Schist, and ${ }^{40} \mathrm{Ar} /{ }^{39} \mathrm{Ar}$ laser step-heating, Sr isotopic, and conodont analyses. These data are used to provide constraints on protolith ages, and the timing of metamorphism, igneous activity, and hydrothermal alteration associated with gold-bearing quartz veins. To help evaluate the area's mineral-resource potential, 215 rocks that were either visibly mineralized or had features that suggested the potential to be mineralized, were analyzed for geochemical trace elements (Werdon and others, 2005).

The surficial-geologic maps show the distribution of unconsolidated deposits and undifferentiated bedrock in the Council and Big Hurrah areas in the Solomon C-5, D-4, and Bendeleben A-4 quadrangles. They were prepared principally by the interpretation of 1:63,360-scale, falsecolor, infrared aerial photographs and multi-scale, multiband satellite imagery. They are locally verified by ground observations during field visits in 2002, 2003, and 2004. Surficial geology in this area was previously mapped at a reconnaissance (1:250,000-scale) level by D.S. Kaufman in 1986 and his mapping was used as a baseline and guide with which to target areas for closer inspection. While the current maps show distinct differences in many of their details as well as in the larger-scale interpretation of some of the glacial stratigraphy, much of the general breakdown of geologic units owes credit to the Kaufman (1986) map.

The surficial-geologic maps were derived in part from a DGGS NASA-funded project to apply remote sensing imagery, Digital Elevation Models (DEMs), and high altitude color-infrared photography in conjunction with knowledge of geomorphology, surficial deposits, and bedrock geology, to evaluate the placer gold potential of part of the Council mining district. As part of this project, we evaluated the utility of Landsat-7 ETM+ multispectral imagery (30 m resolution) in distinguishing key geomorphic features on a regional scale by applying remote sensing analysis techniques that included three-dimensional image drapes using the USGS National Elevation Database (NED) DEM (60 $\mathrm{m}$ resolution). Edge detection using a combination of visible and infrared bands (bands $3,4,5$ ) gave the maximum interpretability of classes of edges, allowing distinctions to be made between bedrock and clouds, major streams and wetlands, minor streams, and sea and lake ice. Principal Components analysis using combinations of one of the first three PC bands with two of the higher PC bands (4, 5, and 6) results in images where wetlands formed in areas of permafrost-rich silt and peat (e.g., McCarthy's Marsh) can be discerned by their color and texture. Unsupervised classification was effective in distinguishing wetlands and other saturated substrates, water (streams, lakes, and ocean), sea and lake ice, snow, silty colluvium, and better-drained uplands and transitional areas. While we were able to distinguish many key geomorphic features in this phase, critical distinctions could be not made at this scale regarding important groups of glacial deposits. The second phase of the project evaluated Quickbird multispectral imagery (2.4 m resolution) used in conjunction with DEMs derived from ERS tandem mission SAR data (30 m resolution) to generate high-resolution three-dimensional image drapes. These data were field checked and combined with analysis of 1:63,360scale, false-color, infrared aerial photograph steropairs and orthophotos to generate the final geologic maps.

\section{DISCUSSION OF GEOLOGY}

Bedrock geologic units in the Big Hurrah and Council map areas primarily are part of the Precambrian to Paleozoic, blueschist-facies metamorphosed Nome Group. Along the northern edge of the Council map, amphibolite-facies rocks (including staurolite schist, and undifferentiated pelitic schist and arc-related amphibolite) are present in high-angle-fault contact with the Nome Group along the south side of the Bendeleben Mountains. Although these rocks are higher in metamorphic grade, their protoliths may be equivalent to those of the Nome Group (Till and others, 1986). The amphibolite-facies rocks are described in the unit description section. Volumetrically minor, Cretaceous to Quaternary alkali gabbro dikes and Cretaceous syenite dikes are the only other rocks that crop out in the two map areas.

\section{NOME GROUP METASEDIMENTARY AND METAIGNEOUS ROCKS LITHOLOGIC CHARACTER AND AGE}

The Nome Group is a regionally extensive suite of rocks that covers most of the Seward Peninsula of Alaska, and was penetratively deformed during the Jurassic at blueschist facies (Forbes and others, 1984; Thurston, 1985; Till and others, 1986). Till and others (1986) in their 1:250,000-scale geologic map of the Solomon, Bendeleben, and southern Kotzebue quadrangles, interpreted the Solomon Schist and Casadepaga Schist (originally defined by Smith, 1910) as being part of the Nome Group (originally defined by Collier and others, 1908 and Moffit, 1913). Till and others (1986) 
also included (and defined) the Mixed Unit, Impure Marble unit, and isolated marble bodies containing conodonts of Devonian through Cambrian age in the Nome Group. Although the marble bodies overlap the age range of the Nome Group, their pre-metamorphic relationships to the other units of the Nome Group are uncertain. DGGS's mapping (this study) follows Till and others' (1986) primary breakdown of units, but we have further subdivided these units on the basis of their lithologic composition and suggest different relative ages. The Nome Group is composed of interlayered metasedimentary and metaigneous rocks, including schist, mafic schist, mafic granofels, marble, impure marble, quartzite, and metagraywacke. Below, we discuss the Nome Group units in the Big Hurrah and Council map areas from oldest to youngest.

The Mixed Unit is dominantly composed of metasedimentary rocks, including pelitic schist, marble, impure marble, siliceous schist, graphitic schist, and graphitic quartzite. Rare thin mafic schist layers are also present. The most characteristic feature of the Mixed Unit is its considerable lithologic variability. In the map areas, units of the Mixed Unit lack significant epidote-group minerals (usually $<2$ percent), which distinguishes them from the generally epidote- and clinozoisite-rich Casadepaga Schist units. Graphite is also largely restricted to the Mixed Unit. Mapping by Bundtzen and others (1994) in the Nome Quadrangle indicates that the Mixed Unit contains rocks identified as felsic metavolcanic rocks, which are not present in the Big Hurrah or Council map areas.

Radiometric and conodont ages, and field relationships from the map area and surrounding region indicate that the protolith of the Mixed Unit ranges from Proterozoic through at least Ordovician in age. The Cape Nome orthogneiss, located $32 \mathrm{~km}$ southwest of the southwestern corner of the Big Hurrah map, is interpreted in this study to intrude the oldest portion of the Mixed Unit. This orthogneiss has an upper-intercept, conventional U-Pb zircon age of $676 \pm 15$ Ma (Patrick and McClelland, 1995). Thus, this portion of the Mixed Unit is of Proterozoic age or older. In the Solomon C-5 and D-4 quadrangles, the Mixed Unit contains abundant carbonate rocks that yielded a single Ordovician conodont age determination (Till and others, 1986). Eleven samples of fine-grained, primarily dolomitic marble from the map areas were submitted for conodont separation as part of this study; no macro- or microfossils were identified in any of the samples. It is unclear whether the nonfossiliferous character is due to Proterozoic age or to poor fossil preservation. Based on the single conodont date, an Ordovician age is likely for the younger portion of the Mixed Unit in the map areas. Strontium isotopic ratios for carbonate rocks from the Mixed Unit are compatible with both Ordovician (sample 80-155-1, table 1; data from outside of this study area) and Proterozoic (from marble located topographically on top of Casadepaga Schist in the eastern Big Hurrah map area; sample 04JEA127A; table 1; fig. 2) ages. At the current state of knowledge, we can neither distinguish between Proterozoic and Ordovician Mixed Unit, nor do we know if intermediate-age or younger Mixed Unit is present in the map areas. Northeast of the Bendeleben Mountains, the Mixed Unit and Casadepaga Schist were intruded by a granitic orthogneiss with a conventional U$\mathrm{Pb}$ zircon age of $381 \pm 2 \mathrm{Ma}$, hence, the Mixed Unit in that
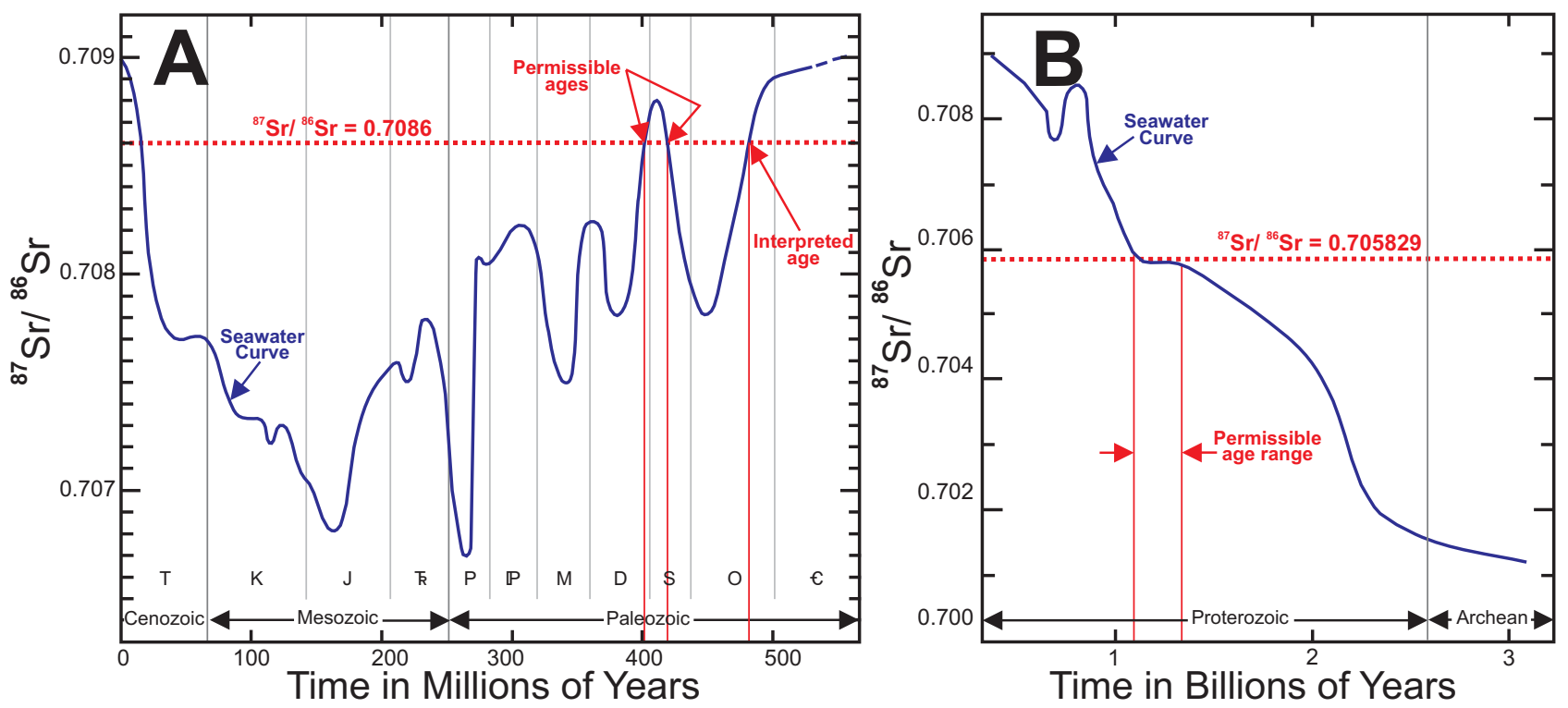

Figure 2. Sr isotopic data for marble from Mixed Unit. A = a single isotopic analysis from Armstrong and others $\left(1986 ;{ }^{87} \mathrm{Sr} /{ }^{86} \mathrm{Sr}=\right.$ 0.7086) indicating permissible Early Devonian, Silurian, or Ordovician ages; interpreted Ordovician age of Mixed Unit micaceous marble is in agreement with conodont evidence. $B=$ a single isotopic analysis from this study $\left({ }^{87} \mathrm{Sr} /{ }^{86} \mathrm{Sr}=0.705829\right)$, indicating Proterozoic age of Mixed Unit marble, in agreement with field relationships that parts of the Mixed Unit were intruded by Proterozoic granitoids. These data confirm that the Mixed Unit is a complex mixture of ages as well as lithologies. Sr isotopic composition of seawater curves from Faure (1986). 
Table 1. Rb-Sr data for whole rock samples of metabasite, metagraywacke, and mixed metasedimentary-metavolcanic rocks from the Casadepaga Schist, and marble from the Mixed Unit

\begin{tabular}{|c|c|c|c|c|c|c|c|c|c|}
\hline Sample \# & $\begin{array}{c}\text { UTM }^{\mathbf{a}} \\
\text { Easting }\end{array}$ & $\begin{array}{l}\text { UTMa }^{\mathrm{a}} \\
\text { Northing }\end{array}$ & Quad & $\begin{array}{c}\mathrm{Rb} \\
(\mathrm{ppm})\end{array}$ & $\begin{array}{c}\mathrm{Sr} \\
(\mathrm{ppm})\end{array}$ & ${ }^{86} \mathrm{Rb} /$ & ${ }^{87} \mathrm{Sr} /$ & Description & leference $^{b}$ \\
\hline $80-155-1$ & 443389 & 7203411 & $\begin{array}{l}\text { Nome } \\
\text { D-3 }\end{array}$ & 29.0 & 1081 & 0.077 & 0.7086 & $\begin{array}{l}\text { Impure calcite marble with } \\
\text { inclusions of white mica, albite, } \\
\text { quartz, and sulfide }\end{array}$ & A \\
\hline 80-117-1 & 473891 & 7268193 & $\begin{array}{c}\text { Teller } \\
\text { C-2 }\end{array}$ & 6.0 & 1041 & 0.01666 & 0.7062 & $\begin{array}{l}\text { Metabasite; thin section } \\
\text { description suggests it has a low } \\
\mathrm{TiO}_{2} \text { content, hence, it may be } \\
\text { equivalent to unit } € g \text { (this study) }\end{array}$ & A \\
\hline $81-119^{c}$ & 528982 & 7177752 & $\begin{array}{l}\text { Solomon } \\
\text { C-5 }\end{array}$ & 136 & 130 & 3.024 & 0.7280 & $\begin{array}{l}\text { Casadepaga Schist metavolcanic } \\
\text { unit; equivalent to unit } € \text { sg of } \\
\text { this study }\end{array}$ & A \\
\hline $80-142-3$ & 501467 & 7259903 & $\begin{array}{l}\text { Bendeleben } \\
\text { B-6 }\end{array}$ & 60.6 & 110 & 1.5924 & 0.7187 & $\begin{array}{l}\text { Listed as pelitic schist, but epidote } \\
+ \text { sphene in thin section suggests } \\
\text { major metavolcanic component. } \\
\text { Unit unknown }\end{array}$ & A \\
\hline $80-118-1$ & 473657 & 7267824 & $\begin{array}{l}\text { Teller } \\
\text { C-2 }\end{array}$ & 1.6 & 533 & 0.009 & 0.7053 & $\begin{array}{l}\text { Mafic rock; possibly Casadepaga } \\
\text { Schist }\end{array}$ & A \\
\hline $80-41-4^{c}$ & 493282 & 7191552 & $\begin{array}{l}\text { Nome } \\
\text { D-1 }\end{array}$ & 168 & 70.7 & 6.869 & 0.7609 & $\begin{array}{l}\text { Sample from Thurston's (1985) } \\
\text { 'chloritic schist and mafic schist } \\
\text { unit'. Probablyequivalent to } \\
\text { Casadepaga Schist(?) }\end{array}$ & A \\
\hline $80-91-2^{c}$ & 484911 & 7161305 & $\begin{array}{c}\text { Nome } \\
\text { C-1 }\end{array}$ & 166 & 45.3 & 10.592 & 0.7867 & $\begin{array}{l}\text { Epidote-bearing unit described as } \\
\text { 'bottom of Casadepaga Schist or top } \\
\text { of Mixed Unit' (T.K. Bundtzen, } \\
\text { written commun., 2005) }\end{array}$ & p \\
\hline 80-151-1 & 489893 & 7217566 & $\begin{array}{c}\text { Teller } \\
\text { A-1 }\end{array}$ & 6.5 & 271 & 0.069 & 0.7047 & $\begin{array}{l}\text { Described as metabasite, but thin } \\
\text { section description indicates it is a } \\
\text { rock with metamafic and } \\
\text { metasediment components }\end{array}$ & A \\
\hline $04 \mathrm{RN} 21 \mathrm{~A}^{\mathrm{d}}$ & 542639 & 7171311 & $\begin{array}{l}\text { Solomon } \\
\text { C-5 }\end{array}$ & 45.0 & 160.5 & 0.8122 & $\begin{array}{r}0.715564 \\
\pm 0.000008\end{array}$ & $\begin{array}{l}\text { Casadepaga Schist metavolcanic } \\
\text { unit (unit } € \text { sg) }\end{array}$ & B \\
\hline 04MBW55A ${ }^{\mathrm{d}}$ & 541865 & 7172173 & $\begin{array}{l}\text { Solomon } \\
\text { C-5 }\end{array}$ & 70.3 & 96.5 & 2.1121 & $\begin{array}{r}0.724029 \\
\pm 0.000008\end{array}$ & $\begin{array}{l}\text { Casadepaga Schist metavolcanic } \\
\text { unit (unit } € \text { sg) }\end{array}$ & B \\
\hline $04 \mathrm{RN} 40 \mathrm{~A}^{\mathrm{d}}$ & 542242 & 7169134 & $\begin{array}{l}\text { Solomon } \\
\text { C-5 }\end{array}$ & 187.5 & 132.5 & 4.1034 & $\begin{array}{r}0.725719 \\
\pm 0.000008\end{array}$ & $\begin{array}{l}\text { Metasedimentary rock from } \\
\text { Casadepaga Schist (unit } € \text { sg) }\end{array}$ & B \\
\hline 04MBW826A ${ }^{\mathrm{d}}$ & 542747 & 7178560 & $\begin{array}{l}\text { Solomon } \\
\text { C-5 }\end{array}$ & 123.0 & 69.9 & 5.1036 & $\begin{array}{r}0.727791 \\
\pm 0.000008\end{array}$ & $\begin{array}{l}\text { Metasedimentary rock from } \\
\text { Casadepaga Schist (unit €sg) }\end{array}$ & B \\
\hline 04MBW836A ${ }^{\mathrm{d}}$ & 543871 & 7177222 & $\begin{array}{l}\text { Solomon } \\
\text { C-5 }\end{array}$ & 162.5 & 76.1 & 6.1922 & $\begin{array}{r}0.726088 \\
\pm 0.000009\end{array}$ & $\begin{array}{l}\text { Metasedimentary rock from } \\
\text { Casadepaga Schist (unit } € \text { sg) }\end{array}$ & B \\
\hline 04JEA127A ${ }^{\mathrm{d}}$ & 545331 & 7173195 & $\begin{array}{l}\text { Solomon } \\
\text { C-5 }\end{array}$ & 11.5 & 2557 & 0.0130 & $\begin{array}{r}0.705829 \\
\pm 0.000011 \\
\end{array}$ & $\begin{array}{l}\text { Marble from Mixed Unit } \\
\text { (unit Op€m) }\end{array}$ & B \\
\hline
\end{tabular}

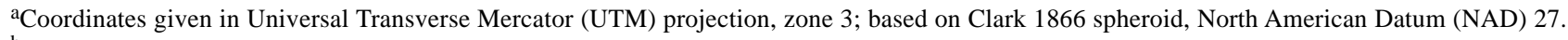

${ }^{\mathrm{b}} \mathrm{A}$ = Data from Armstrong and others (1986); B = Data from this study.

'Sample described as pelitic schist by Armstrong and others (1986), but locations on maps by DGGS (this study), Thurston (1985), and T.K. Bundtzen (written commun., 2005) indicate these samples came from a non-pelitic unit.

${ }^{\mathrm{d} A n a l y s t}=$ Dr. Dominique Weis, Pacific Center for Isotope and Geochemical Research, University of British Columbia, Canada. Protolith interpretation based on modal mineral percentages observed in thin section (this study) and major-oxide data (Werdon and others, 2005). 
region is pre-Middle Devonian or older (Till and others, 1986; Till and Dumoulin, 1994).

The Casadepaga Schist is composed of interlayered metasedimentary and metaigneous rocks, including pelitic schist, intermediate-composition schist and semi-schist interpreted herein as metamorphosed graywacke (fig. 3) of approximately andesitic composition, and lesser mafic schist layers. Isolated mafic granofels bodies (unit $€$ g) are also considered part of the Casadepaga Schist, and probably represent small intrusions or flows(?). Hence, the Casadepaga Schist is interpreted to represent a metamorphosed volcanic-sedimentary sequence. Mafic schist and mafic granofels bodies within the Casadepaga Schist display arctype trace-element characteristics (Werdon and others, 2005; this study, fig. 4). The Casadepaga Schist has a highly variable magnetic character in airborne magnetic data (Burns and others, 2003), typical of volcanic sequences, reflecting dominantly the variable sphene vs. rutile vs. ilmenite and (or) magnetite content.

Our assigned Cambrian age for the Casadepaga Schist is based on a whole-rock $\mathrm{Sr}$ isochron age of approximately $540 \mathrm{Ma}$ for metavolcanic rocks of andesitic composition, which are assumed to have the same initial strontium isotopic composition (data from Armstrong and others, 1986; this study, table 1, fig. 5). The Cambrian age is consistent with the pre-Middle Devonian age constraint for the Casadepaga Schist provided by the granitic orthogneiss north of the Bendeleben Mountains (Till and others, 1986; Till and Dumoulin, 1994).

Metamorphosed gabbroic dikes, sills, and plugs (unit DOg) intruded the Casadepaga Schist, and to a lesser extent the Mixed Unit. Major-oxide and trace-element data indicate these bodies have an extensional, within-plate tectonic setting (Barker, 1994; this study, fig. 4). Very high $\mathrm{TiO}_{2}$ contents for unit DOg (typically $>3$ weight percent) suggests intrusive rather than extrusive crystallization for these rocks. Basalt (extrusive mafic rocks), as shown by a compilation of several thousand basalt analyses representing a variety of tectonic settings and ages, rarely exceeds about 3 weight percent $\mathrm{TiO}_{2}$ (fig. 6).

Unit DOg is constrained to be younger than Cambrian, because it intrudes the Cambrian Casadepaga Schist. If these metabasites intruded the Ordovician portion of the Mixed Unit, unit DOg is constrained to be younger than Ordovician.

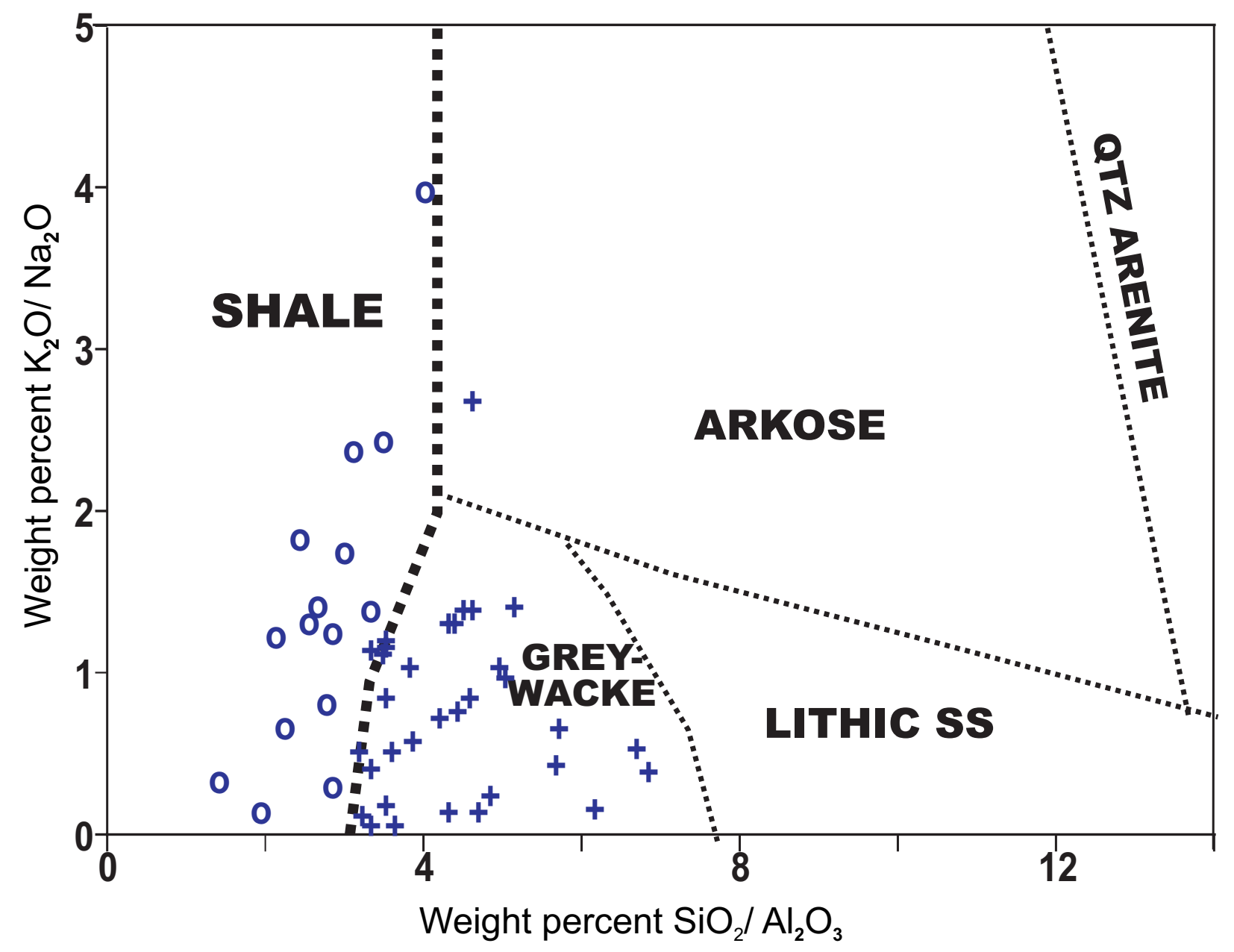

Figure 3. Casadepaga Schist metagraywacke $(+)$ and pelitic schist $(O)$ are distinguished on the basis of relative weight percent ratios of $\mathrm{K}_{2} \mathrm{O} / \mathrm{Na}_{2} \mathrm{O}$ versus $\mathrm{SiO}_{2} / \mathrm{Al}_{2} \mathrm{O}_{3}$. Lithologic discrimination diagram modified from Rollinson, 1993. Data from Buxton (1990); Werdon and others (2005). 


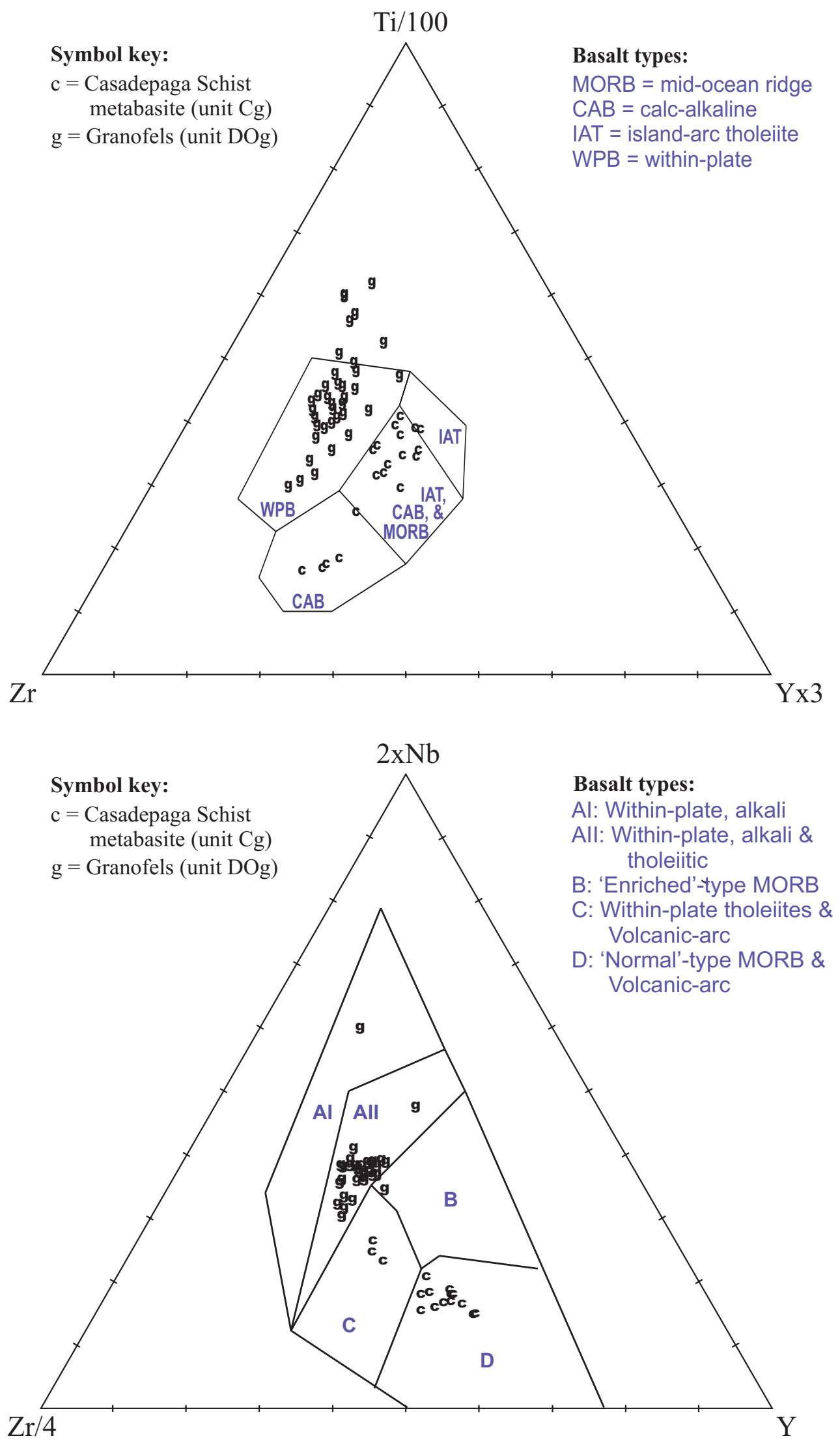

Figure 4. Metamorphosed mafic rocks from the Big Hurrah and Council map areas plotted on $\mathrm{Ti}-\mathrm{Zr}-\mathrm{Y}$ and $\mathrm{Nb}-\mathrm{Zr}$-Y tectonic discrimination diagrams for basalts (upper figure after Pearce and Cann, 1973; lower figure after Meschede, 1986). Data from Werdon and others (2005). 


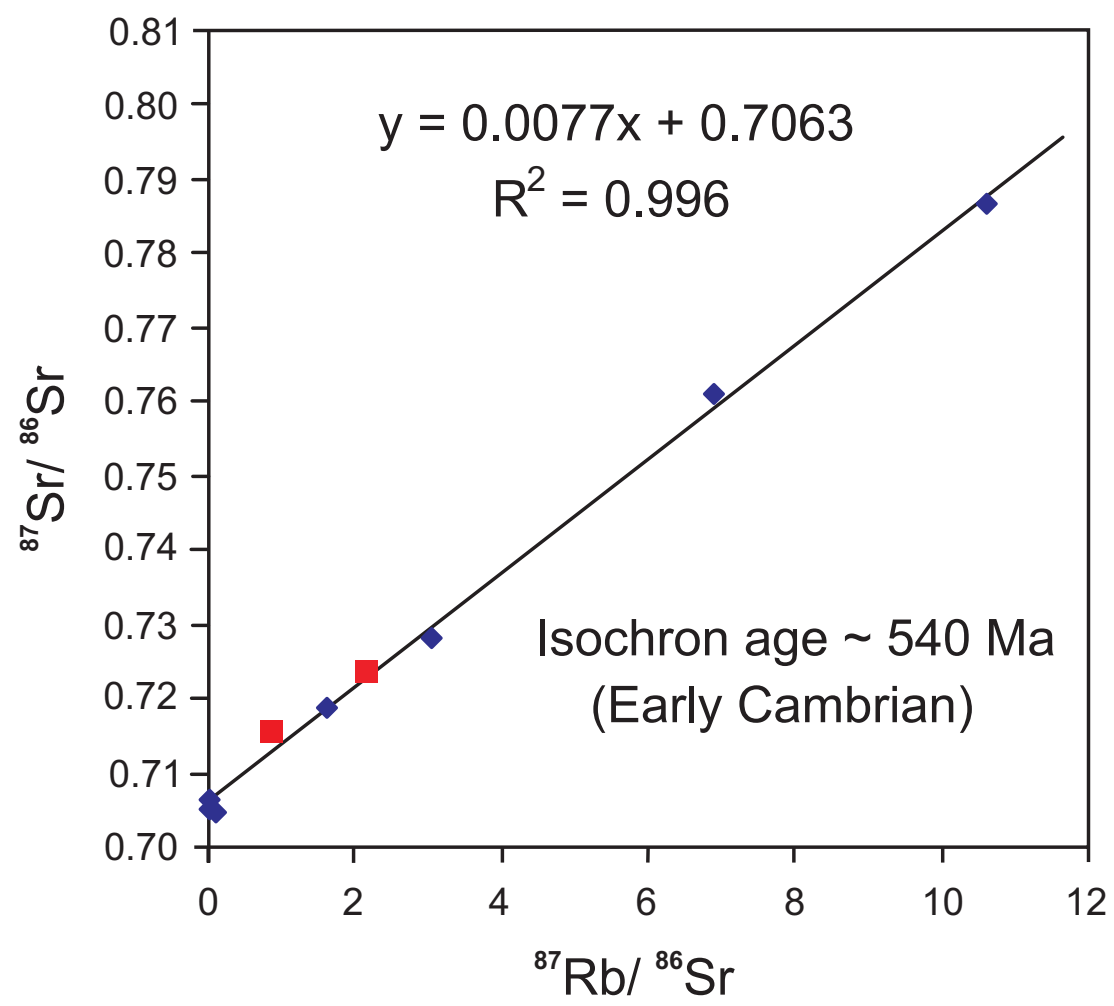

Figure 5. $R b$-Sr isochron for metabasite and metavolcanic rocks of the Casadepaga Schist. Data from Armstrong and others (1986; blue diamonds); this study (red squares). Data points for samples containing non-metavolcanic (sedimentary) components plot off from this isochron due to variable $\mathrm{Sr}_{i}$ (initial strontium), and are not shown.

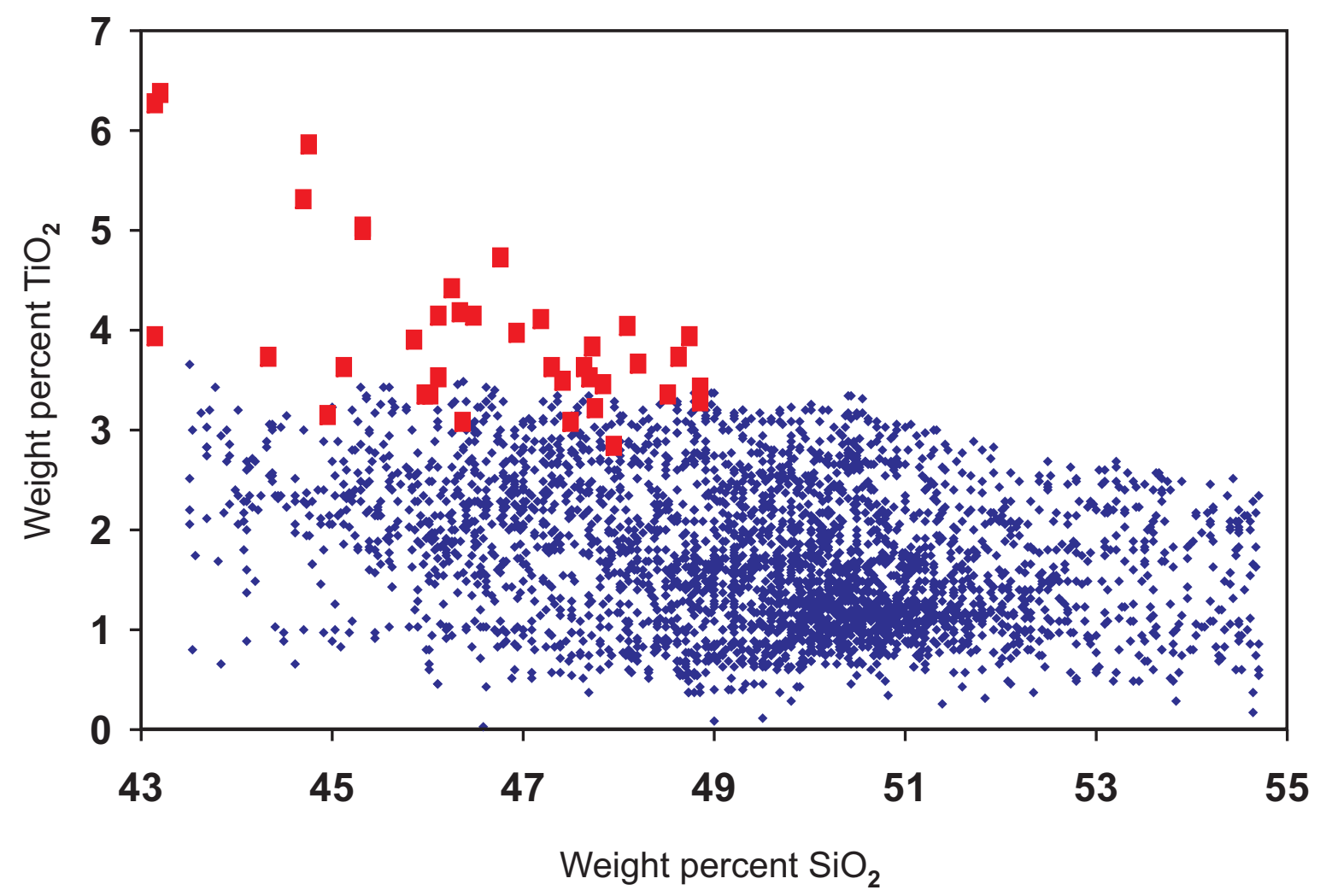

Figure 6. Composition of 3,221 analyses of basalt (blue diamond), with an average $\mathrm{TiO}_{2}$ content of $1.7 \pm 0.7$ weight percent (Mutschler, 1981), relative to metabasite from unit DOg (red squares), which shows relatively high $\mathrm{TiO}_{2}$ and low $\mathrm{SiO}_{2}$ (analyses from Buxton [1990]; Werdon and others [2005]). The low $\mathrm{SiO}_{2}$ content of unit DOg suggests these metabasites are not highly fractionated, and that the chemistry is consistent with an intrusive origin. 
Because these metabasites exhibit blueschist-facies mineral assemblages, unit DOg must be older than the Jurassic metamorphism (as indicated by highest-temperature-fraction ${ }^{40} \mathrm{Ar} /{ }^{39} \mathrm{Ar}$ ages of $\sim 200 \mathrm{Ma}$ for barroisite [Na-Ca amphibole]). Modeling of partially reset ${ }^{40} \mathrm{Ar} /{ }^{39} \mathrm{Ar}$ spectra for barroisite supports a Devonian ( 400 Ma), premetamorphic crystallization age for this unit (map location A9; table 2).

The Solomon Schist is characterized by its highly uniform pelitic composition, general absence of graphite, and abundance of chloritoid. The Solomon Schist was historically viewed as the oldest unit in the Nome Group due to the numerous recumbent, isoclinally folded quartz veins that were thought to represent a pre-Paleozoic deformation (for example, Smith, 1910; Young, 1995). Our mapping shows identical textures in pelitic layers of the Mixed Unit and unit $€$ sg of the Casadepaga Schist. Further, $\mathrm{U}-\mathrm{Pb}$ age determinations on detrital zircons from Solomon Schist indicate Ordovician to late Middle Devonian sources for the protolith (A.B. Till and J.M. Amato, written commun., 2005), hence, a post-late Middle Devonian age. The prominent isoclinal, recumbent folds are thus due to bulk composition and rheological rock properties and not to an older deformational event that was not encountered by other Nome Group rocks.

\section{RELATIONSHIPS BETWEEN NOME GROUP UNITS}

The spatial geometry, stratigraphic, and (or) structural relationships between units of the Nome Group prior to Jurassic blueschist-facies metamorphism are largely unknown. Field observations, interpretations of geochemical data, and dating work completed as part of this study allow us to suggest permissible relationships between the Mixed Unit, Casadepaga Schist, and Solomon Schist.

In the Council and Big Hurrah map areas, the Mixed Unit both topographically underlies and overlies the Casadepaga Schist. Lithologic layering is commonly subparallel to foliation, suggesting transposition of original layering. In the simplest interpretation, interlayering of these units could reflect preservation of pre-metamorphic, original stratigraphic relationships because the Mixed Unit is both older and younger than the Casadepaga Schist. It is also possible that regional-scale, recumbent isoclinal folding produced repetition of the units.

However, truncations of lithologic layering commonly are present along Mixed Unit-Casadepaga Schist contacts. Lithologic truncations could reflect either a pre-metamorphic unconformable contact, a pre-metamorphic fault contact, or structural juxtaposition of the Mixed Unit and Casadepaga Schist during and (or) after ductile deformation related to the blueschist-facies metamorphic event. Contacts between the Casadepaga Schist and the Mixed Unit are shown on the Council and Big Hurrah maps as a dashed red line, reflecting the uncertainty of the contact's origin. Our preferred interpretation is that Mixed Unit-Casadepaga
Schist contacts in the map areas do not reflect original stratigraphic order.

In most areas, lack of protolith age determinations for Nome Group units precludes determining whether youngerover-older relationships are present. Although the Devonian or younger Solomon Schist usually topographically overlies the older Mixed Unit, in the south-central part of the Big Hurrah map the Mixed Unit overlies the Solomon Schist. Similarly, in the eastern part of the Big Hurrah map area, Proterozoic-marble-bearing Mixed Unit topographically overlies the Cambrian Casadepaga Schist. The local, olderover-younger age relationships suggest that at least some of the contacts between Nome Group units are faults. Foliationparallel slip may have occurred during or after ductile deformation, but poor exposure in most cases limits determination of the presence of brittle features (if any) along the contacts.

Although the types of pre-metamorphic contacts between the Casadepaga Schist and the Mixed Unit are poorly known, geologic relationships suggest these units were in proximity to each other prior to Jurassic time. Near the western edge of the Big Hurrah map, Mixed Unit marble (unit $\mathrm{Op} € \mathrm{~m}$ ) is intruded by a blueschist-faciesmetamorphosed mafic dike, which has a trace-elementindicated, volcanic-arc tectonic setting. If the Mixed Unit at this locality is older than the Cambrian Casadepaga Schist, this dike may be a feeder dike for the arc-related mafic bodies (unit $€ g$ ) within the Casadepaga Schist. The dike would also require the Casadepaga Schist and the Proterozoic portion of the Mixed Unit to be in spatial proximity to each other by Cambrian time. Alternatively, if this dike intrudes the Ordovician portion of the Mixed Unit, the dike is unrelated to unit $€$ g, and it represents a pre-Jurassic, mafic igneous event of unknown association and age. Dating of the Mixed Unit and metamorphosed mafic dike are needed to determine the correct interpretation.

The extension-related mafic bodies (unit DOg), which intrude both the Casadepaga Schist and the Mixed Unit, require these two units to be in spatial proximity to each other prior to Devonian time. These extension-related metagabbroic intrusions are not known to be present in the Solomon Schist in the Council and Big Hurrah map areas, or elsewhere on the Seward Peninsula. The Solomon Schist is nowhere in contact with Casadepaga Schist. Because the Solomon Schist is late Middle Devonian or younger, it may have either stratigraphically or unconformably overlain the Ordovician portion of the Mixed Unit, or have been structurally juxtaposed with the Mixed Unit during ductile deformation.

\section{METAMORPHISM}

The Nome Group underwent Jurassic blueschist-facies metamorphism and deformation (Forbes and others, 1984; Thurston, 1985; this study). Metamorphism progressed from early blueschist-facies conditions, to lower albite-epidoteamphibolite facies, and then to greenschist facies conditions 


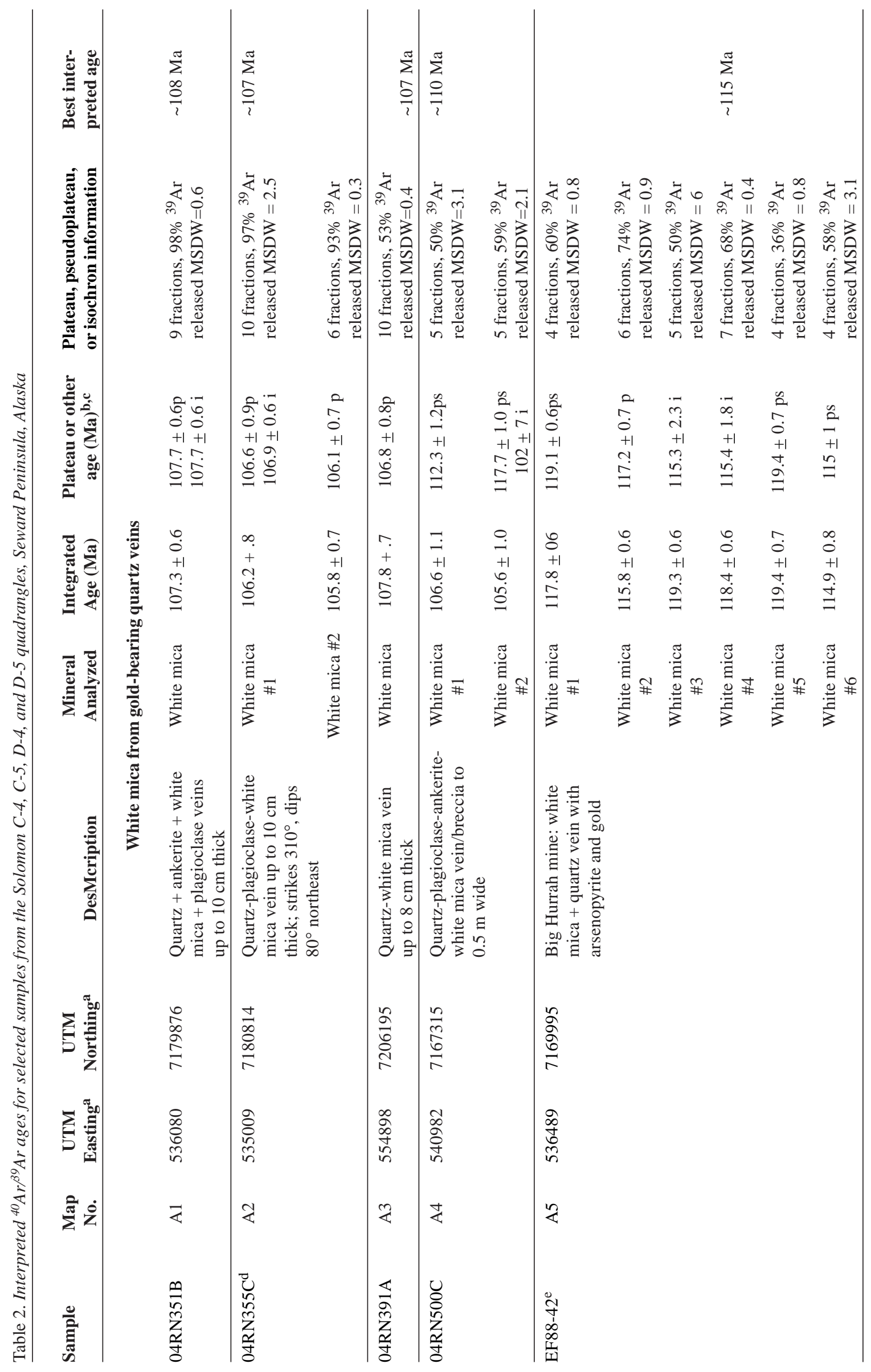




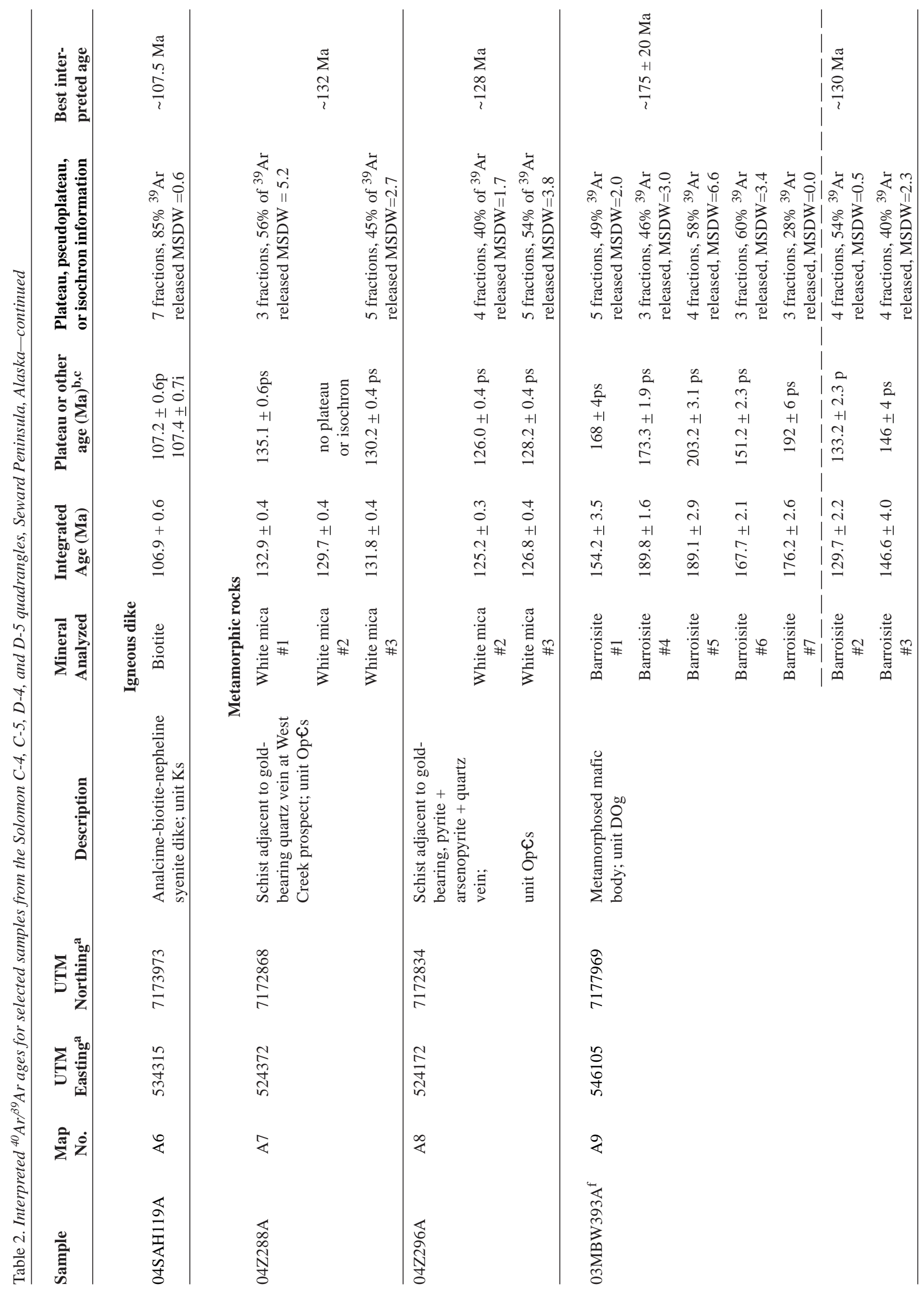




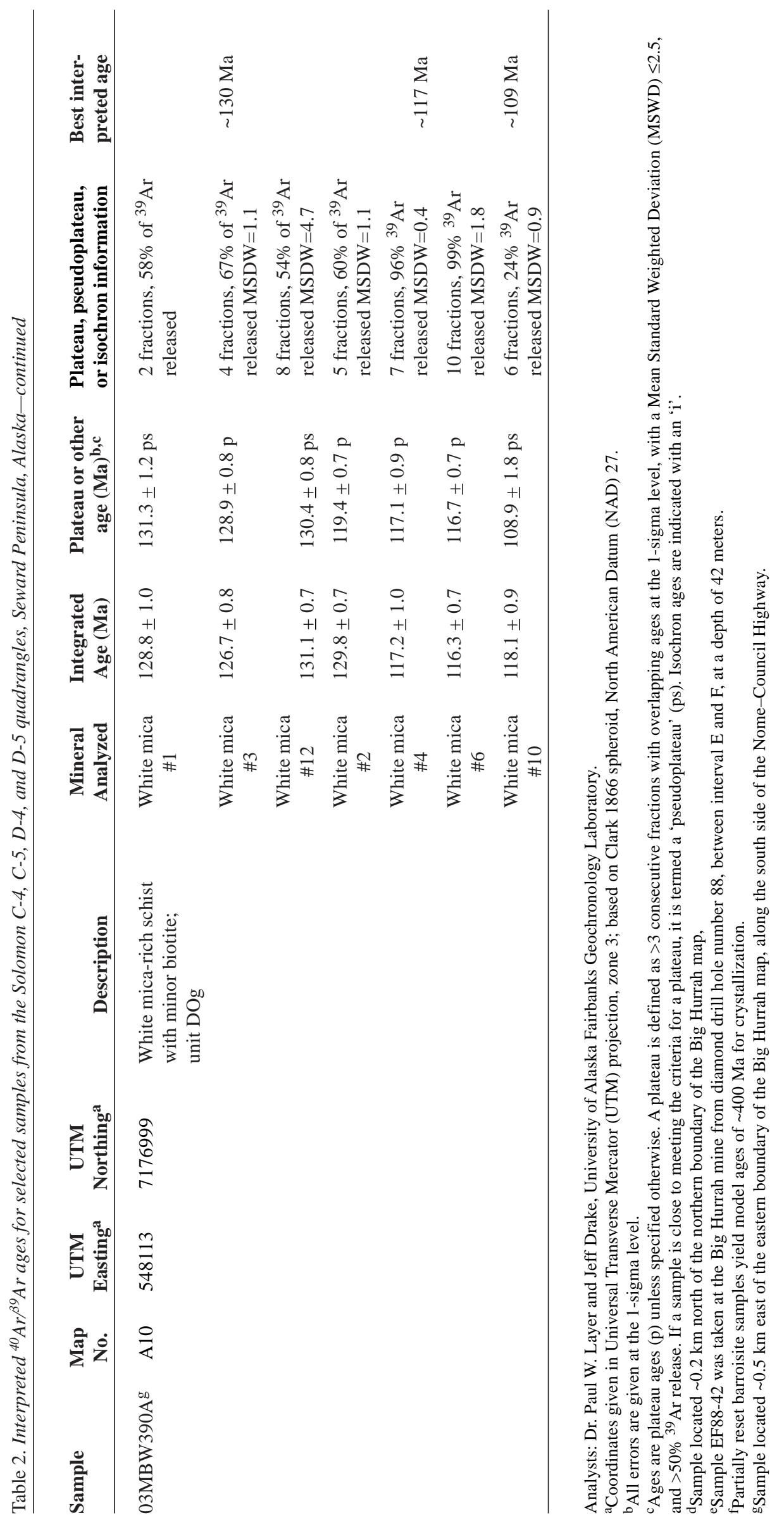


(Thurston, 1985). The assemblage glaucophane + actinolite + epidote + garnet was stable during the blueschist phase; textural relations indicate that barroisite, a sodic-calcic amphibole, crystallized later, in the albite-epidoteamphibolite facies. Occasional rims of actinolite on barroisite, or more rarely on glaucophane, indicate mineral growth during greenschist facies conditions. Variable degrees of hydration during post-blueschist-facies metamorphism have resulted in variably retained blueschistfacies mineral assemblages. In the map areas, rocks of appropriate bulk composition display a variety of mineral assemblages, ranging from nearly pristine ferroglaucophane (microprobe determination) + epidote + garnet + sphene, to extensively retrograded rocks containing diamond-shaped aggregates of fine-grained plagioclase + chlorite, which are interpreted to represent glaucophane pseudomorphs formed during greenschist facies conditions. The persistence of these pseudomorphs suggests that recrystallization was commonly not accompanied by penetrative deformation. Local biotite replacement of chlorite and white mica likely either represents greenschist-facies metamorphism or thermal anomalies above buried Cretaceous intrusions. In the map area it is not clear how much deformation, if any, took place at greenschist-facies conditions.

Based on high Ca/K fractions from barroisite with ${ }^{40} \mathrm{Ar} /$ ${ }^{39} \mathrm{Ar}$ ages of $\sim 200 \mathrm{Ma}$, blueschist-facies metamorphism took place before the Middle Jurassic (fig. 7; map location A9; table 2). Based on plateau ages of 130 Ma for white micas (map locations A7, A8, A10; table 2) and cooling ages of $\sim 130$ Ma for low $\mathrm{Ca} / \mathrm{K}$ fractions in barroisite, cooling to greenschist-facies conditions took place by Early Cretaceous. These data suggest a long period of slow cooling from peak pressure-temperature conditions. Ages as old as 119 Ma obtained from white micas in gold veins indicate that the Nome Group was deformed in the brittle realm at that time. Brittle deformation and associated hydrothermal fluid flow took place - continuously or sporadically-to approximately $107 \mathrm{Ma}$ as indicated by the younger ages for vein white micas (map locations A1-A5; table 2).
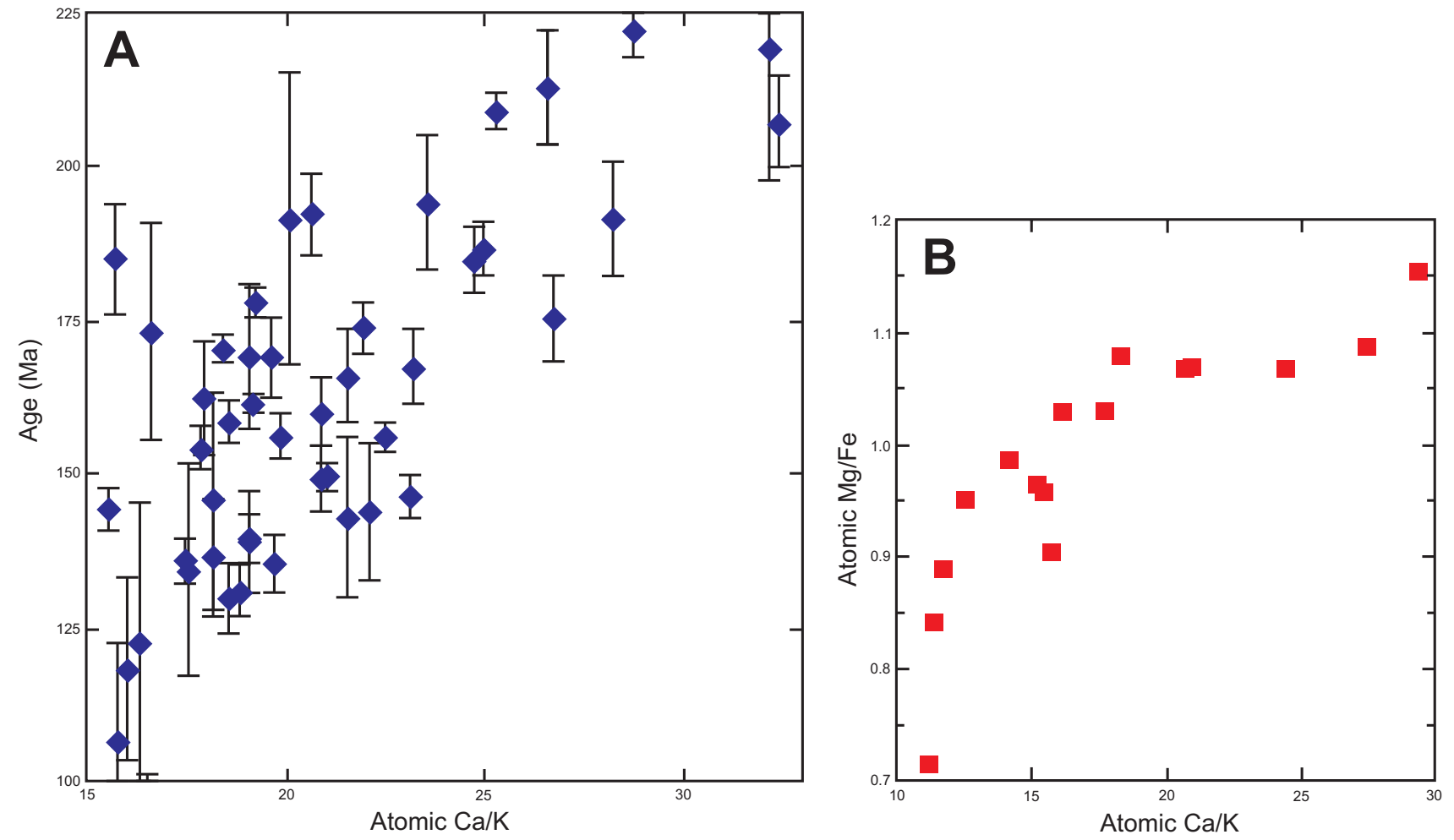

Figure 7. A. ${ }^{40} \mathrm{Ar} /{ }^{39} \mathrm{Ar}$ step-heating fraction data for repeated runs of barroisite from sample 03MBW393A.

B. Microprobe analyses of barroisite from sample 03MBW393A. All microprobe analyses of barroisite contain $\sim 7$ percent CaO, while $\mathrm{K}_{2} \mathrm{O}$ varies continuously from 0.24 to 0.56 weight percent; thus, the high-K barroisites have low Ca/K and also low Mg/Fe. Due to the smaller unit cell size, minerals with higher $\mathrm{Mg} / \mathrm{Fe}$ ratios retain argon at higher temperatures relative to the same mineral with lower Mg/Fe ratios. The combination of age and compositional data indicates that the higher Mg/Fe barroisite fractions record the time when the sample was at a higher temperature ( $450^{\circ} \mathrm{C}$ ?); the lower $\mathrm{Mg} / \mathrm{Fe}$ barroisite records the time when the sample had cooled to a significantly lower temperature $\left(\sim 350^{\circ} \mathrm{C}\right.$ ?). As supported by microprobe analyses, amphiboles with lower Ca/K ratios (shown in figure A using the ${ }^{37} \mathrm{Ar} /{ }^{39} \mathrm{Ar}$ ratio as a proxy for $\mathrm{Ca} / \mathrm{K}$ ) are closer in composition to actinolite; those with higher ratios to barroisite. The actinolitic amphibole fractions yield younger ages due to their formation during retrograde metamorphism ( 150$130 \mathrm{Ma}$ ); the barroisitic amphibole fractions yield approximate ages of blueschist- or immediately post-blueschist-facies metamorphism ( 200 Ma). 


\section{STRUCTURES}

Both ductile and brittle structures are present in the Big Hurrah and Council map areas. These features reflect the complex structural history encountered by the Nome Group, spanning the time from Jurassic blueschist-facies metamorphism and deformation, through high-angle faulting that offsets Quaternary glacial deposits along the Bendeleben Fault along the southern margin of the Bendeleben Mountains.

As discussed earlier, an undisturbed, younger-overolder stratigraphic sequence is not an appropriate interpretation for the current spatial distribution of Nome Group units. Map patterns suggest Nome Group units were deformed, folded, and faulted together during ductile deformation. In the south-central part of the Big Hurrah map, where Mixed Unit overlies the younger Solomon Schist, we interpret the contact as a folded low-angle fault. Although Mixed Unit-Casadepaga Schist contacts exhibit lithologic truncations, and the nature of these contacts is uncertain, they appear to have been folded together early in the cycle of deformation. As all Nome Group units have encountered broadly similar metamorphic conditions, it is likely that lowangle faults occurred prior to or during the JurassicCretaceous metamorphic-structural event. However, given the absence of information about specific pressuretemperature conditions encountered above and below surfaces with lithologic truncations, we cannot rule out some post-metamorphic movement.

The most obvious ductile structures are isoclinal folds, visible on scales ranging from millimeters to kilometers. Isoclinal recumbent folds are most obvious in the Solomon Schist, but can be seen in metasedimentary and metavolcanic rocks of all the units of the Nome Group. Isoclinal folds, with limbs parallel to foliation, commonly have northnortheast-trending fold axes (fig. 8). These folds most likely represent the earliest fold generation, which formed during ductile deformation. Foliation in the Big Hurrah area is largely flat lying, and foliation in the Council map area dips slightly to the east (fig. 8).

In the northeastern corner of the Big Hurrah map, a low-angle fault with brittle deformation is exposed on a prominent, steep-sided, cinder-cone-shaped hill, nicknamed

\section{BIG HURRAH MAP}
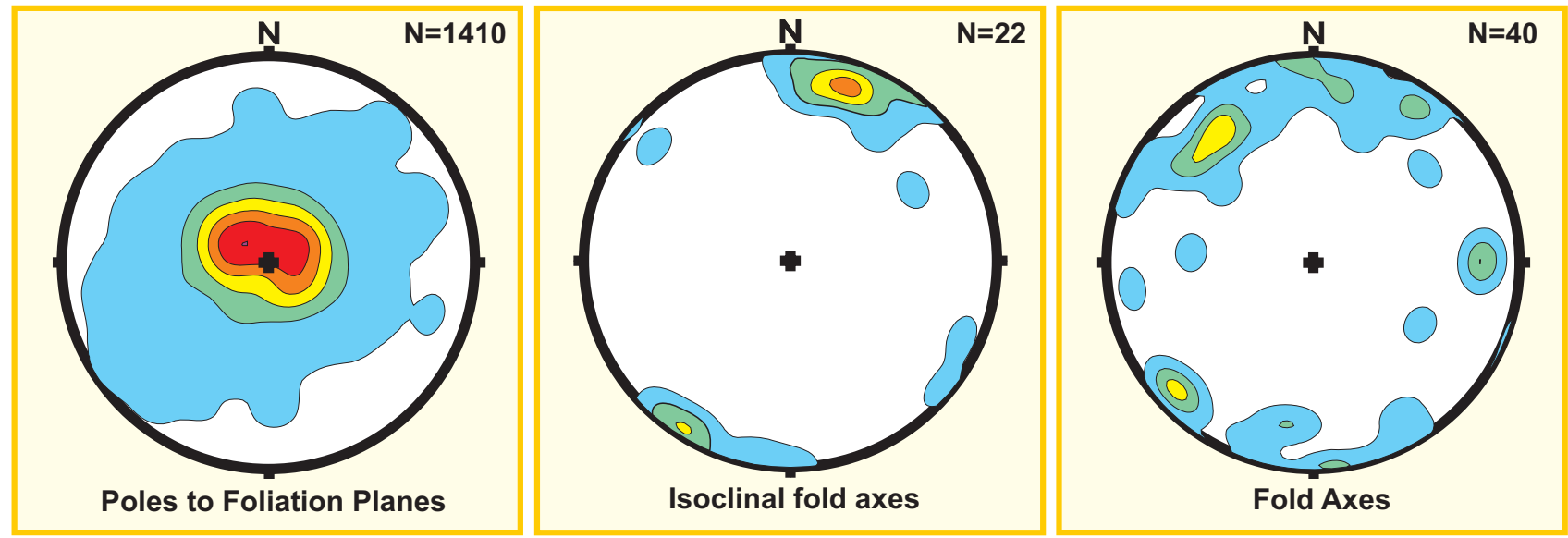

\section{COUNCIL MAP}
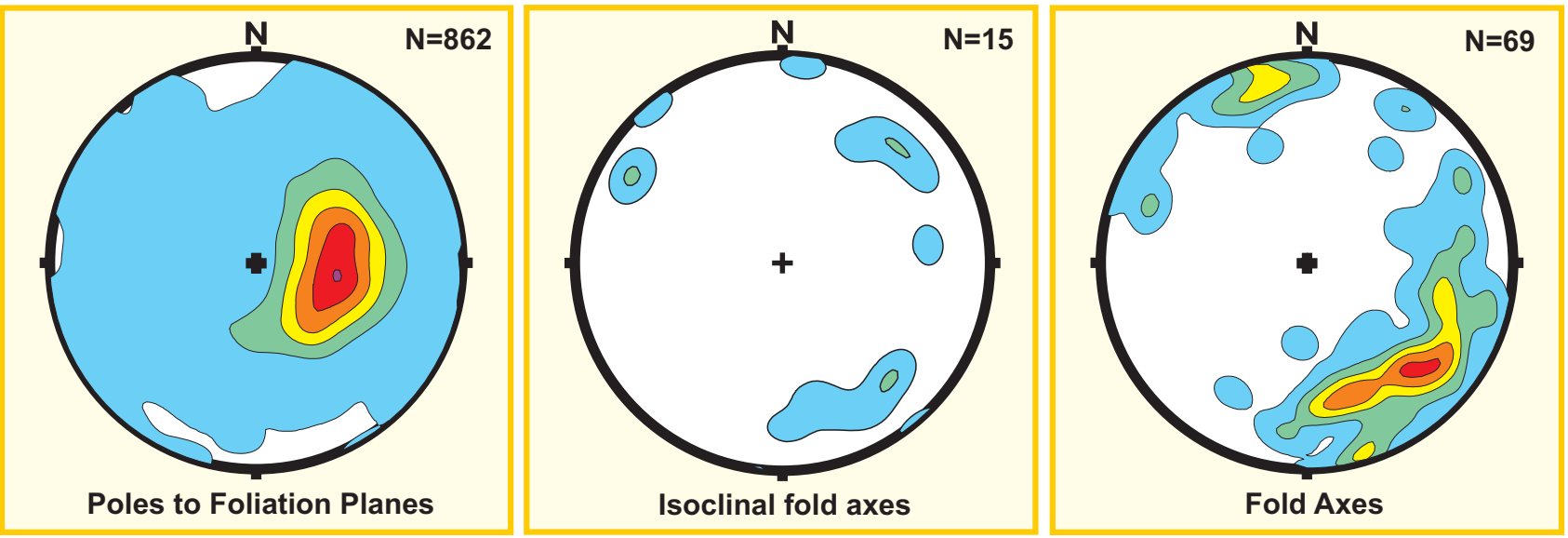

Figure 8. Lower-hemisphere, Schmidt equal-area stereonet plots of poles to foliation, and trend and plunge of isoclinal and non-isoclinal fold axes, for the Big Hurrah and Council map areas. 
the "Glaucophane Volcano" (based solely on its volcanolike shape). The topographically highest, upper block consists of Casadepaga Schist (unit $€$ sg) and mafic granofels (unit DOg). These units structurally overlie an approximately 75-m-thick zone of folded, faulted, and quartz-veined Mixed Unit lithologies (see Big Hurrah map and cross-section A$\left.A^{\prime}\right)$. Beneath this zone, Casadepaga Schist (unit $\boldsymbol{\ell}_{\text {sg) }}$ ) and mafic granofels (unit DOg), again overlie Mixed Unit lithologies. The nature of this lower contact is unknown; there is no obvious zone of brittle deformation associated with it. The brittle, low-angle fault exposed at the "Glaucophane Volcano" demonstrates that low-angle faulting occurred after ductile deformation, but the timing and lateral extent are unknown.

Broad-scale folds, as indicated by map patterns of the units and folded foliation, are recognized as folds with northeast-, north-, and northwest-trending axes that occur throughout the Council and Big Hurrah map areas. Folds with north-northeast-trending fold axes appear to represent the youngest generation of folding in the Big Hurrah map area. In the southeastern Council map area, northwesttrending fold axes are dominant, and are parallel to highangle faults.

High-angle faults throughout the two map regions are much more obvious than folds; they are expressed as linear topographic depressions, and discontinuity zones on airborne geophysical maps (Burns and others, 2003). Prominent fault orientations are northwest, north-south, and northeast; the former two generally truncate the latter. In most cases the displacements are better explained as largely dip-slip, rather than strike-slip. Locally, drag folds are present adjacent to high-angle faults, and indicate the sense of motion. Gold-bearing quartz veins, and rare, extensionrelated alkalic dikes occurred at about 107-115 Ma, as recorded by ${ }^{40} \mathrm{Ar} /{ }^{39} \mathrm{Ar}$ ages of hydrothermal white mica associated with gold-bearing quartz veins (Ford and Snee, 1996; this study, map locations A1-A5, table 2) and biotite from a syenite dike in the Big Hurrah map area (this study, map location A6, table 2). Both high- and low-angle faults host gold-bearing quartz veins, and in many cases, these faults appear to have been active during quartz deposition. Calc-alkaline intrusions with subduction-related, trace- and major-element compositions and ages of approximately 90$100 \mathrm{Ma}$ are common in the high-grade metamorphic rocks of the central Seward Peninsula (Amato and others, 2003). A return to extension-related tectonics in the Tertiary to Quaternary is indicated by alkalic mafic igneous activity and associated high-angle faulting. Quaternary alkalic basalt flows and their associated northwest-trending vent site crop out along Bear River in the Solomon D-5 Quadrangle, located approximately halfway between the southern edge of the Council map and the northeast corner of the Big Hurrah map (Till and others, 1986; Werdon and others, 2003). Sparse mafic dikes of unknown age are scattered throughout the map areas, and may be related to igneous activity during Cretaceous to Quaternary time. A graben along the Niukluk River is supported by the map pattern, and more than $75 \mathrm{~m}$ of gravel (of probable Tertiary to Quaternary age) reported from placer gold drilling on the bench between Bear and Fox rivers in the Council map area. A late, east-west-trending, north-side-up, high-angle normal fault exposes high-grade amphibolite-facies rocks of the Bendeleben Mountains along the north edge of the Council map. This fault, and other nearby high-angle faults, offset Quaternary glacial deposits along the south side of the Bendeleben Mountains.

\section{MINERALIZATION}

Since the turn of the century, more than 1 million ounces of placer gold have been mined from the region covered by DGGS's Council airborne geophysical survey. Throughout the Big Hurrah and Council map areas there are many lowsulfide, gold-bearing quartz veins that are likely the primary lode sources for the placer gold. The best-known locale is the historic Big Hurrah lode gold mine, which is currently being reevaluated by the mineral industry. Other notable lode gold areas include the Silver (Flynn) mine and the West Creek prospect. The Proterozoic to Paleozoic Nome Group also has the potential for metasediment-hosted, stratabound, base-metal-sulfide lode occurrences.

In the Big Hurrah and Council map areas, low-sulfide, gold-bearing, quartz \pm arsenopyrite \pm stibnite \pm iron sulfides \pm white mica \pm graphite \pm carbonate \pm plagioclase veins are preferentially hosted by graphitic \pm calcareous \pm pyritic schist and quartzite in the Mixed Unit. Such rocks may have supplied reduced sulfur necessary for carrying gold in solution as hydrogen sulfide (HS) complexes, and $\mathrm{CO}_{2}$ necessary to cause fluid effervescence at moderate pressures and temperatures. In the Big Hurrah map area, both lowand high-angle faults were structurally active during gold deposition; many of the gold-vein-hosting high-angle faults strike northwest. At the Big Hurrah and Silver (Flynn) mines, native gold is paragenetically late; it is primarily deposited on top of graphite-coated fracture surfaces that are present in sheared (ribbon-textured) quartz veins (Read and Meinert, 1986; this study). The veins are variably anomalous in $\mathrm{Au}$, $\mathrm{Ag}, \mathrm{As}$, and $\mathrm{Sb}$, with minor associated $\mathrm{Cu}, \mathrm{Zn}, \mathrm{Pb}$, and $\mathrm{W}$ (Werdon and others, 2005). White mica from gold-bearing veins in the Solomon C-4, C-5, D-4, and D-5 quadrangles yielded ages of approximately 107-115 Ma (map locations A1-A5; table 2). Gold-bearing quartz veins in the Big Hurrah and Council map areas are chemically and mineralogically similar to those in the Nome Quadrangle, and hence, potentially have a similar genetic origin. $\mathrm{A} \mathrm{Pb}$ secondary isochron for 11 vein samples from the western Seward Peninsula (fig. 9) yielded an age of approximately $500 \mathrm{Ma}$, consistent with derivation of lead from a sub-local (Nome Group) metal source.

The base-metal, mineral-resource potential of the Nome Group is poorly understood, and it is the focus of a current study by the U.S. Geologic Survey (A.B. Till, written commun., 2004). Lithologies of the Nome Group are permissible for hosting base-metal-sulfide deposits. For example, graphitic quartzite of the Mixed Unit, with its high 
modal quartz and graphite content, could represent anoxic sediments deposited in a restricted basin environment. Also present within the Council and Big Hurrah map areas are volumetrically insignificant copper occurrences that are preferentially located near the contact between schist and marble within the Mixed Unit. Chalcopyrite \pm iron sulfides are present as disseminated grains, and locally, the marble is partially to completely silicified. Most of these occurrences are poorly exposed (frost action has reduced the rocks to rubble) but one silicified zone in marble, including its associated disseminated copper and iron sulfides, is present along a northeast-trending high-angle fault in the Solomon C-5 Quadrangle on the hill located approximately $1 \mathrm{~km}$ northwest of the mouth of Big Hurrah Creek (Asher, 1969; Werdon and others, 2005).

\section{SURFICIAL GEOLOGY}

Glacial deposits mapped in the study area were assigned to glacial episodes according to the chronology developed by Kaufman and Hopkins (1986) and Kaufman (1986), and include Nome River drift, Sinuk drift, and an undifferentiated Sinuk or pre-Sinuk drift. Nome River drift, the youngest glacial deposits in the map area, is believed to be of middle Pleistocene age based on radiometric dating of basaltic lava by Kaufman and others (1991). Nome River moraines have been extensively modified by slope processes and are typically overlain by up to $1+\mathrm{m}$ of windblown silt. Surfaces are completely vegetated, somewhat smooth to slightly hummocky, and rarely develop local bogs and ponds.

\section{Secondary Isochron for Seward Peninsula veins}

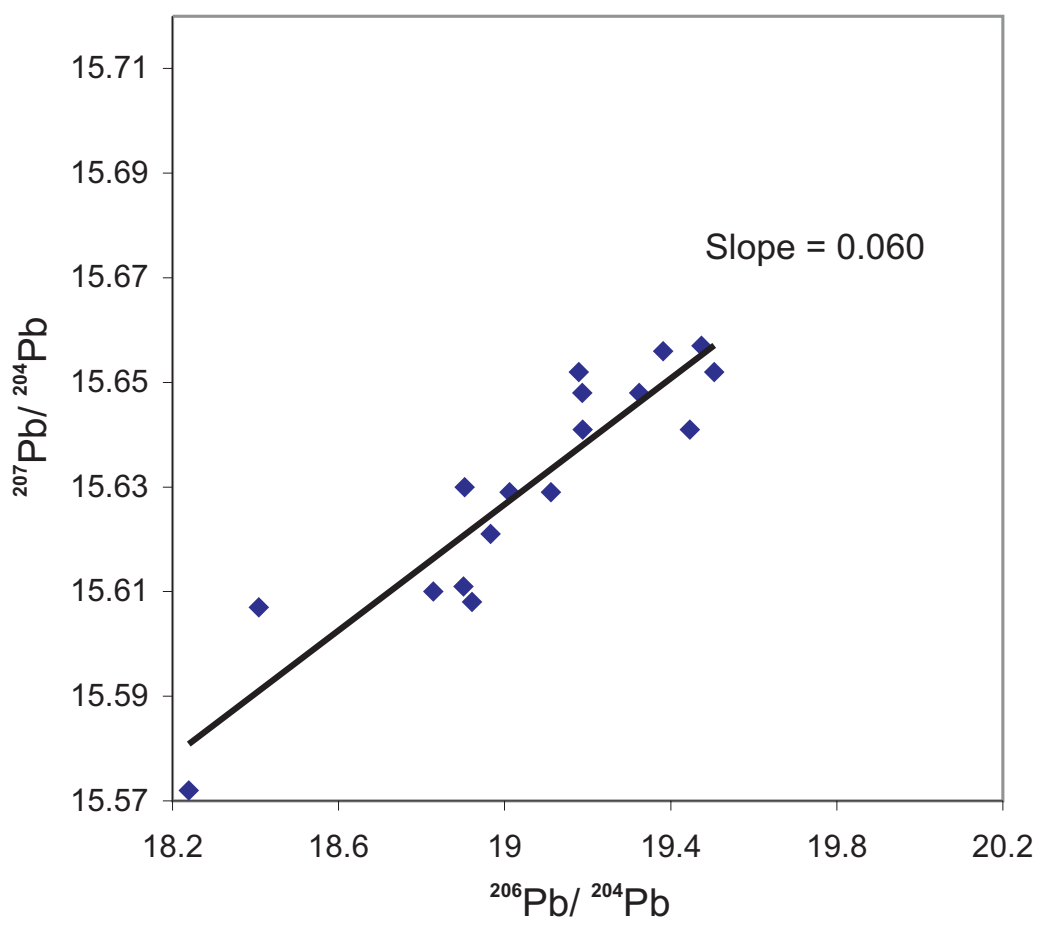

Gross primary morphology is retained and the deposits form pronounced, arcuate ridges that are readily identified as moraines that are up to $3.5 \mathrm{~km}$ wide, with crests up to $75 \mathrm{~m}$ above modern river level. Nome River moraines extend at least $5 \mathrm{~km}$ beyond the mountain front in the Bendeleben Mountains. Sinuk drift is significantly more modified than Nome River drift, and the surface is characterized by numerous thaw ponds and bogs as well as incised drainages. Gross primary morphology is largely lost, although broad, sweeping moraine crests can still be discerned. Sinuk moraines extend at least $10 \mathrm{~km}$ beyond the mountain front in the Bendeleben Mountains and almost $15 \mathrm{~km}$ to the coast in the Solomon area. The highly subdued moraines are up to $4 \mathrm{~km}$ wide with remnant crests up to $75 \mathrm{~m}$ above modern river level. Undifferentiated Sinuk or pre-Sinuk drift is represented by a scattering of erratic boulders, many of which are perched individually or in clusters directly on scoured bedrock surfaces. The higher elevation and distribution beyond the limits of Sinuk drift suggest that the erratics were deposited by an older, more extensive glaciation than the Sinuk, although a Sinuk age for these deposits cannot be ruled out.

The area around Council consists primarily of colluvium-draped hills of moderate relief drained by moderate- to low-gradient (9 m per kilometer and less) streams. Niukluk River bisects the southern part of the area, draining formerly glaciated uplands in the northwest and flowing through a major fault-bounded basin that heads near the mouths of Richter and Ophir creeks. The river follows this basin through the marshy lowlands south and southeast of Council and ultimately drains into Golovnin Lagoon via a large delta system. Niukluk River is flanked by terrace deposits along most of its length in the study area. Smith and Eakin (1911) describe a hole that was sunk in 1906 on a surface $50 \mathrm{ft}$ (15 m) above the river and midway between Fox and Bear Creeks. The hole reached a depth of $250 \mathrm{ft}$ (75 m), all through gravel, indicating that the lowland silt deposits mapped upslope of the lower terraces are underlain by

Figure 9. Lead secondary isochron from goldbearing quartz veins throughout the Seward Peninsula (data from Gaccetta and Church, 1989; Ford, 1993). Data are compatible with a source age of 510 Ma for a mobilization age of $\sim 110 \mathrm{Ma}$. 
gravels as well. The upper contacts of these lowland silt deposits conform to the locations of photolinears that delineate the margins of the fault-bounded basin through which the river flows and generally mark the western extent of the down-dropped block or blocks. The distribution and orientation of the photolinears, coupled with the topographic relief in this area, suggest en echelon style faulting.

The northeastern portion of the Council map area is dominated by glacial deposits derived from ice flowing from the Bendeleben Mountains to the north. Prior to glaciation, the headwaters of Ophir Creek drained eastward into McCarthy Marsh, a large fault-bounded basin on the south side of the Bendeleben Mountains. By middle Pleistocene time glaciers of Sinuk age had advanced beyond the mountain front, crossed the McCarthy Marsh lowlands, and locally overtopped drainage divides into Ophir and Melsing Creek basins. Fine-grained sediments and bedded sands in upper Ophir Creek indicate a small lake probably formed in the headwaters as the river was dammed by advancing glaciers. The lake waters ultimately overtopped the drainage divide to the south and carved the deep, narrow, steep-walled canyon that forms the modern course of upper Ophir Creek. Glacial meltwater flowing into the headwaters of Ophir, Snowball, and Melsing creeks deposited gravels and boulders with characteristic Bendeleben Mountain lithologies, and locally formed benches that may be correlative with "pocket bench" placers described by Collier and others (1908) perched $120 \mathrm{ft}$ (36 m) above creek level on the east side of Ophir Creek.
The Big Hurrah portion of the study area is characterized by topographically higher and more rugged terrain than the Council map area and is dominated by north-northwestfacing cirques. Solifluction deposits are extensive on many slopes and display spectacular lobate forms. Based on headwall and valley morphology many of the peaks probably supported cirque glaciers during very old glaciations, but no deposits are readily observable, except in the western portion of the study area. The oldest and most extensive glacial deposit is a Sinuk or pre-Sinuk undifferentiated drift. The limit of this deposit was generally mapped according to the maximum elevation and lateral extent of numerous glacial erratics. During this glaciation, ice overtopped the divide into Johnson Creek in the northwest part of the map area and joined with a major ice stream in the Casadepaga River basin to the north. It is unclear whether these erratics are of Sinuk age or if they are older, hence they have been mapped as Sinuk or pre-Sinuk drift. Glacial deposits that Kaufman (1986) confidently assigned to the Sinuk glaciation are confined to the western part of the map area. West of the map area, large glaciers in Bonanza and Eldorado creeks flowed onto the coastal plain and extended laterally along the mountain front across lower Shovel Creek and Solomon River. The south fork of Quartz Creek flows through a prominent broad, steep-walled channel that cuts south through the ridge separating Big Hurrah Creek from the coastal plain. This channel may have been an outlet of a lake in the Solomon River basin that was dammed by the large ice lobe from the west.

\section{DESCRIPTION OF MAP UNITS UNCONSOLIDATED DEPOSITS}

Terms used to describe the estimated percentages of cobbles and boulders are 'numerous', 'scattered', and 'rare.' 'Numerous' implies that drilling through the layer would encounter two cobbles or boulders in an interval of $0.6 \mathrm{~m}$; 'scattered' implies that drilling would encounter two cobbles or boulders in an interval of 3 to $4.5 \mathrm{~m}$; and 'rare' implies that drilling would encounter two cobbles or boulders in an interval of more than $4.5 \mathrm{~m}$. Estimated content of gravel, sand, and silt, based on field observations, is indicated by the terms 'some' and 'trace.' 'Some' implies a general composition of 12 to 30 percent. 'Trace' implies a general composition of 4 to 12 percent. Estimated compositions of less than 4 percent were not recorded in the field.

\section{ALLUVIAL DEPOSITS}

Qas SILTY ALLUVIUM (Holocene) - Broad, elongate deposits of moderately well stratified silt and minor fine sand beneath modern channels and floodplains of streams draining silt-mantled slopes. Generally composed of reworked eolian silt. May include fine-grained debris-flow deposits, especially in the upper reaches. Moderately to well sorted and medium to thin bedded; locally crossbedded. Surface smooth except for local shallow, interconnected channels and low scarps. Mapped in Klokerblok and Skookum River valleys and near the headwaters of Big Hurrah Creek in the Big Hurrah area.

Qfp FLOODPLAIN ALLUVIUM (Holocene) - Elongate deposits of moderately to well sorted, well stratified, fluvial gravel, sand, and silt with scattered to numerous boulders forming modern floodplains and associated low terraces. Deposits may reflect former channels and flow regimes. Medium to thick bedded, locally crossbedded, shows fining-upward cycles, and may be locally auriferous. Clasts generally rounded. Typically mantled by thin layer of silty overbank deposits. Generally finer grained than similar deposits in Qal unit because of deposition during floods. May locally include latest Pleistocene to Holocene terrace alluvium. 
Lower surfaces may be flooded during periods of high stream discharge. Ground ice content highly variable, but generally expected to be low. Surface typically well vegetated, smooth to hummocky with local low scarps and bogs. Mapped along Niukluk River in the Council area.

Qal ALLUVIUM, UNDIFFERENTIATED (Quaternary) - Elongate deposits of moderately to well sorted, well stratified, fluvial pebble-cobble gravel, sand, and silt, with scattered to numerous boulders, deposited in active stream channels, floodplains, and associated low terraces. Deposit is medium to thick bedded, locally crossbedded, shows fining-upward cycles, and is locally auriferous. Clasts generally rounded. Extensive willowalder thickets grow on many Qal deposits in mature valley fills. Surface smooth to hummocky except for local low scarps.

Qat TERRACE ALLUVIUM (Quaternary) - Elongate deposits of well sorted, well rounded to subrounded pebblecobble gravel and sand with trace to some silt and rare to numerous boulders composing stream terraces bordering modern floodplains and clearly related to modern drainage. Surface smooth except for local low scarps.

\section{COLLUVIAL DEPOSITS}

Qrg ROCK GLACIER DEPOSITS (Holocene) - Tongue-shaped heterogeneous mixtures of angular to subangular blocks of local bedrock and ice with trace to some gravel, sand, and silt at depth that accumulate on floors and lower walls of cirques by flow of rock glaciers derived from shrinking of former glaciers (ice cored) or from deposition and cementation of precipitation-derived ground ice (ice cemented). Perennially frozen where active. Probably generally clast-supported. Surface furrowed, pitted, or hummocky and covered with angular to subangular blocks. Single possible example mapped in northern part of Council map area.

Qc COLLUVIUM, UNDIFFERENTIATED (Quaternary) - Irregular, heterogeneous blankets, aprons, and fans of angular to subrounded rock fragments, gravel, sand, and silt that are left on slopes, slope bases, or high-level surfaces by residual weathering and complex mass-movement processes, including rolling, sliding, flowing, gelifluction, and frost creep. May include greatly modified drift of older glaciations. Locally washed by meltwater and slope runoff. Medium to thick bedded. Generally unsorted to very poorly sorted. Thickness is highly variable, with thickest deposits at the bases of slopes. Surface disturbances, such as from excavation, may result in melting of permafrost and subsequent slumping and flowage. Surface smooth, lobed, or terraced and, if deposit is thin, generally reflects configuration of underlying bedrock surface.

Qcs SOLIFLUCTION DEPOSITS (Quaternary) - Irregular drapes of poorly sorted mixtures of angular rock fragments of local origin with trace to abundant sand and silt deposited on slopes primarily by soil creep (gelifluction/solifluction). Deposits on upper slopes and hills consist of irregular drapes and sheets of coarse ( $\geq 1$ meter blocks are common), angular rock fragments and rubble with minor silt, sand, and gravel deposited more or less in place by block weathering and frost riving. Deposits on lower slopes consist primarily of silt with varying proportions of angular rock fragments and sand. Deposits are widely subjected to secondary reworking by cryoturbation, including frost heave and frost jacking of rock fragments. Surface smooth to hummocky and gently to moderately sloping with prominent steps and lobes oriented approximately perpendicular to slope.

\section{GLACIAL DEPOSITS}

\section{NOME RIVER GLACIATION}

Qdn DRIFT OF NOME RIVER AGE (middle Pleistocene) - Heterogeneous blanket of pebble-cobble gravel, sand, silt, and clay in varying proportions deposited by glaciers. Contains rare to numerous large $(\geq 1 \mathrm{~m})$ boulders deposited directly from glacial ice. Sorting, bedding, and clast roundness highly variable, depending on degree of water reworking. Deposit locally includes or is gradational with outwash. Typically overlain by up to 1+ meter of windblown silt. Surface smooth to highly irregular with uncommon local bogs and ponds. Forms broad, arcuate ridge at head of Ophir Creek. 


\section{SINUK GLACIATION}

Qds DRIFT OF SINUK AGE (early? Pleistocene) - Heterogeneous blanket of pebble-cobble gravel, sand, silt, and clay in varying proportions deposited by glaciers. Contains rare to numerous boulders ( $\geq 1.6$ meter) deposited directly from glacial ice. Sorting, bedding, and clast roundness highly variable, depending on degree of water reworking. Deposit may locally include or be gradational with outwash. Observed thickness ranges from a thin and patchy veneer or lag of pebbles, cobbles, and boulders over ice-scoured bedrock in higher elevations to an unknown maximum thickness in lower elevations, where it is mantled by thick ( $>1$ meter), heavily vegetated, reworked silt cover. Surface smooth to highly irregular with local bogs and small ponds. Forms broad, arcuate ridges at head of Ophir Creek, and blankets southwestern corner of Big Hurrah map area.

Qds-v DRIFT OF SINUK AGE, VENEER (early? Pleistocene) - Very thin and patchy veneer of pebbles, cobbles, and boulders deposited directly from glacial ice. Preserved as a scattered lag of exotic cobbles and boulders on and in silty colluvium east of Sardine Creek in upper Ophir Creek area.

Qds-w DRIFT OF SINUK AGE, WASHED (early? Pleistocene) - Meltwater-washed equivalent of Sinuk-age drift (unit Qds). Surface gently to steeply sloping, hummocky, and channeled with lag of coarse cobbles and boulders on surface.

\section{SINUK GLACIATION OR OLDER}

Qdu OLDER DRIFT, UNDIFFERENTIATED (early? Pleistocene) - Deposits of probable glacial origin and uncertain composition and age along Shovel Creek and associated tributaries in the Big Hurrah area. Upper limits mapped primarily on the basis of distribution of glacial erratics composed of lithologies (principally Casadepaga metabasite and some schist) exotic to the local bedrock. Erratics preserved singly or as boulder-cobble lags on glacially scoured bedrock; some are glacially striated; up to $1 \mathrm{~m}$ diameter. Deposits probably thicken downslope where they are thickly mantled by silt and colluvium and are very poorly exposed.

\section{GLACIOFLUVIAL DEPOSITS}

\section{SINUK GLACIATION}

Qds-os SANDY OUTWASH OF SINUK AGE (early? Pleistocene) - Blanket of bedded sand with some washed, rounded to subrounded pebble-cobble gravel and scattered to numerous subangular to rounded boulders deposited by meltwater draining margins of former glaciers terminating in headwaters of Ophir Creek. Includes local fine-grained glaciolacustrine and delta deposits from glacier damming of upper Ophir Creek basin. Thin to thick bedded, locally crossbedded. Surface generally smooth and gently sloping, except for local low scarps.

Qds-ow OUTWASH OF SINUK AGE (early? Pleistocene) - Elongate to irregular heterogeneous mixture of washed, rounded to subrounded pebble-cobble gravel with some sand and silt and scattered to numerous subangular to rounded boulders deposited by meltwater draining margins of former glaciers in headwaters of Ophir and Snowball creeks. Forms terrace deposits along margins of these creeks, and may be correlative with documented “pocket bench" placers of Ophir Creek (Collier and others, 1908). Thin to thick bedded, locally crossbedded. Surface generally smooth and gently sloping, except for local low scarps.

\section{PALUDAL DEPOSITS}

Qs $\quad$ SWAMP DEPOSITS (Holocene) - Elongate to blanket deposits of complexly bedded peat, organic silt, and organic sand accumulated as surface deposits in local basins and in former stream channels. Saturated and locally frozen, locally ice rich. Thickness highly variable. Surface smooth, ridged, mounded, hummocky, or pitted. May have standing water. Mapped in southeast corner of Council area map.

Qtl THAW LAKE DEPOSITS (Holocene) - Semicircular to irregularly shaped deposits of moderately stratified, heterogeneous, brown to dark gray silt, sand, and organic silt filling small, locally interconnected basins resulting from the melting of ice-rich permafrost in silt. Saturated and locally refrozen, locally ice rich. Mapped in southeast corner of Council area map and on Sinuk age drift in northeast corner of Council area map. 


\section{COMPLEX DEPOSITS}

Qls LOWLAND SILT (Quaternary) - Irregular blankets of massive, generally homogeneous, silt and organic silt originally laid down by eolian processes and subsequently minorly to extensively reworked by fluvial and colluvial processes on lower slopes and valley bottoms. May include areas of upland silt (Qus). Includes siltrich debris-flow deposits. Commonly contains angular clasts of local origin and scattered small charcoal fragments and root casts. Generally massive, but locally bedded. Commonly perennially frozen with variable ice content. Maximum observed thickness approximately $1 \mathrm{~m}$, but total thickness is potentially much greater. Surface generally smooth to gently sloping; locally pitted due to melting of ground ice.

Qls-p PERMAFROST-RICH LOWLAND SILT (Quaternary) - Irregular, homogeneous blankets of poorly to moderately stratified silt and organic silt, generally equivalent to Qls unit, that has been extensively modified by development, melting, and regrowth of ice-rich permafrost. Includes semicircular to irregularly shaped deposits of moderately stratified, heterogeneous silt, sand, and organic silt filling small, often interconnected basins resulting from the melting of ice-rich permafrost in silt. Saturated and locally refrozen, locally ice rich. Surface generally smooth to gently sloping with local low-center ice-wedge polygons; locally pitted and gullied by melting of ice-rich permafrost (thermokarst). Surface may be pitted and hummocky or characterized by numerous shallow, interconnected channels; small ponds and boggy areas are abundant.

Qvs UPLAND SILT (Quaternary) - Irregular blankets, fans, and aprons of massive, generally homogeneous, silt originally laid down by eolian processes and subsequently minorly to extensively reworked by fluvial and colluvial processes. Silt is largely retransported by mudflows, slopewash, gelifluction, and frost action. Includes fine-grained colluvium. May contain abundant angular clasts of local origin. Massive to thinly bedded, with some wavy bedding and crossbedding. Thickness is highly variable, with thickest deposits at the bases of slopes. Commonly perennially frozen with variable ice content. Surface smooth and steep to gently sloping.

\section{MANMADE DEPOSITS}

Qmt MINE TAILINGS (Holocene) - Water-washed pebble-cobble gravel with trace to some sand and silt piled in active or former gravel pits, open-pit mines, and dredged areas. Typically well sorted. Surface smooth to irregular or forming symmetrical ridges and cones.

\section{BEDROCK UNITS ON SURFICIAL MAPS}

BEDROCK, EXPOSED - Undifferentiated bedrock with essentially no cover

BEDROCK, THINLY COVERED - Undifferentiated bedrock that is covered by a thin (generally $<1 \mathrm{~m}$ thick) veneer of colluvium, drift, undifferentiated glacial or glaciofluvial deposits, or combinations of these deposits. Cover is sufficiently thin that planar bedrock structures, like joints, foliation, and bedding or glacier-scoured bedrock subcrops are reflected at the ground surface by linear and curvilinear shallow troughs and bands of moist ground or hydrophyllic vegetation.

\section{BEDROCK UNITS}

\section{IGNEOUS ROCKS}

QKg GABBRO DIKES (Quaternary? to Cretaceous?) - Fine-grained, equigranular to locally porphyritic gabbro dikes sparsely distributed throughout the Big Hurrah and Council maps areas. Dikes are brown to orange weathering, dark gray, \pm biotite-phyric, and $\leq 2 \mathrm{~m}$ in width. Modal composition of 0-25 percent clinopyroxene (occasionally concentrically zoned and twinned), 0-10 percent olivine, 0-5 percent orthopyroxene, 10-93 percent feldspar (rarely porphyritic), 0-40 percent biotite, 0-6 percent opaque minerals, trace hornblende, and accessory apatite. Secondary minerals include chlorite, serpentine, talc, sericite, and carbonate. Major- and minor-oxide and trace-element analyses indicate the gabbro dikes are alkalic and formed in a within-plate, extension-related tectonic setting (Werdon and others, 2005). Magnetic susceptibility is high (0.40-16.9, averaging $5.86 \times 10^{-3} \mathrm{SI}$ [Système International]). ${ }^{40} \mathrm{Ar} /{ }^{39} \mathrm{Ar}$ biotite ages are in preparation for several of these dikes. 
SYENITE DIKE (Cretaceous) - Fine-grained, equigranular syenite dike exposed as loose rubble in the road cut just south of the East Fork bridge in the northern half of the Solomon C-5 Quadrangle. Maximum dike width approximately $5 \mathrm{~m}$. Brown weathering, brownish-gray colored. Modal composition of 25 percent nepheline, 26 percent K-feldspar, 10 percent plagioclase, 30 percent biotite, and accessory garnet, magnetite, and apatite. Secondary minerals include analcite, white mica, and carbonate. Has major- and minor-oxide and trace-element characteristics of within-plate, extensional magmatism. Magnetic susceptibility is high (0.981.38, averaging $1.24 \times 10^{-3} \mathrm{SI}$ ). ${ }^{40} \mathrm{Ar} /{ }^{39} \mathrm{Ar}$ biotite plateau age of $107.2 \pm 0.6 \mathrm{Ma}$ (map location A6; table 2). Alkalic dikes and plutons occur elsewhere on Seward Peninsula and yield similar ages (Miller, 1972; Amato and others, 2003).

\section{METAMORPHIC ROCKS}

\section{SEDIMENTARY AND IGNEOUS ROCKS METAMORPHOSED TO BLUESCHIST FACIES: NOME GROUP}

\section{SOLOMON SCHIST}

QUARTZ-WHITE MICA SCHIST (late Middle Devonian or younger) - Fine- to medium-grained, foliated, quartz-rich schist with numerous quartz veins parallel to foliation. Generally contains 20-70 percent quartz, 12-40 percent white mica, $0-30$ percent plagioclase + chlorite pseudomorphs of glaucophane, 5-20 percent chlorite (with white mica:chlorite greater than or equal to 2:1), 0-15 percent chloritoid, and 0-5 percent carbonate. Trace biotite replacing chlorite variably present. Contains $<1.5$ percent accessory minerals including tourmaline (pleochroic colors brown and rare green), apatite, pyrite, ilmenite, rutile, and zircon. Characteristically lacking significant epidote-group minerals ( $<2$ percent) and porphyroblastic feldspar. Protolith is interpreted to be siliciclastic sedimentary rocks. Magnetic susceptibility is low $\left(0.00-0.70\right.$, averaging $\left.0.26 \times 10^{-3} \mathrm{SI}\right)$. Forms a pronounced resistivity low in airborne geophysical data in the Council map area (Burns and others, 2003). Solomon Schist collected at Bermudez Bluff in the Solomon D-5 Quadrangle, located $3 \mathrm{~km}$ west of the western boundary of the Council map, contains a detrital zircon population that is largely Ordovician, but also contains detrital zircons as young as late Middle Devonian (conventional U-Pb analyses of zircon grains; A.B. Till and J.M. Amato, written commun., 2005).

\section{METAIGNEOUS ROCKS}

DOg MAFIC SCHIST AND GRANOFELS (Devonian to Ordovician) - Metaigneous sills, dikes, and plugs that intruded the Casadepaga Schist, and to a lesser extent, parts of the Mixed Unit. Metamorphosed mafic bodies are medium- to dark-green colored, and texturally vary from medium-grained, foliated schist to massive, fineto coarse-grained granofels. Modal composition varies widely, but generally contains 10-20 percent chlorite (4-40 percent range), 10-20 percent epidote + clinozoisite + zoisite (0-30 percent range), 10-15 percent garnet (0-30 percent range, locally porphyroblastic), 0-28 percent plagioclase, and 0-7 percent magnetite plus varying proportions of glaucophane ( $<50$ percent, commonly porphyroblastic), actinolite ( $<10$ percent), and barroisite ( $<20$ percent). Glaucophane is commonly pseudomorphed by fine-grained aggregates of plagioclase + chlorite and in some cases replaced by barroisite. Secondary minerals include quartz ( $<25$ percent), carbonate ( $<15$ percent), white mica $(<5$ percent, with occasional higher values), and biotite ( $<3$ percent, replacing chlorite). Contains trace apatite. High titanium content is expressed as sphene (commonly 10 percent), ilmenite $(<5$ percent), and minor rutile. Unit has an extensional within-plate trace-element chemistry (Werdon and others, 2005). Magnetic susceptibility is variable but usually high (0.00-68.9, averaging $7.05 \times 10^{-3} \mathrm{SI}$ ). In the southwest portion of the Council map, one of these metamorphosed intrusions contains angular xenoliths of graphitic quartzite (Op€q) up to $15 \mathrm{~cm}$ in diameter.

\section{MIXED UNIT}

Op $\epsilon_{\mathrm{x}} \quad$ MIXED METASEDIMENTARY ROCKS (Ordovician to Precambrian) - Composite unit primarily composed of schist (Op€s) with lesser marble (Op€m), impure marble (Op€i), quartzite $(\mathrm{Op} € \mathrm{q})$, and mafic schist (Op€ms). Interlayering of units occurs on meter to tens-of-meters scale. Unit is variably graphitic. Magnetic susceptibility is generally low $\left(0.00-3.41\right.$, averaging $\left.0.11 \times 10^{-3} \mathrm{SI}\right)$. 
Op€i IMPURE MARBLE (Ordovician to Precambrian) - Blocky weathering, medium-grained, foliated, equigranular impure marble that contains millimeter- to centimeter-scale interlayers of calcareous schist and (or) white mica-rich horizons. Gray to light brownish-orange weathering, light gray colored. Composed of 52-84 percent carbonate (calcite and rare dolomite) with 7-20 percent quartz, 2-15 percent white mica, 0-12 percent plagioclase (some porphyroblasts), and 0-10 percent chlorite. Accessory minerals include graphite, rutile, and pyrite. Magnetic susceptibility is low $\left(0.00-0.50\right.$, averaging $\left.0.06 \times 10^{-3} \mathrm{SI}\right)$.

Op€ms MAFIC SCHIST (Ordovician to Precambrian) - Medium-grained, variably porphyroblastic, mafic schist. Gray weathering, light to dark gray colored. Average modal composition approximately 10-70 percent plagioclase as porphyroblasts $\left(\sim \mathrm{An}_{15}-\mathrm{An}_{20}\right), 20-30$ percent chlorite (10-94 percent range), 10-30 percent quartz (0-52 percent range), and 0-20 percent white mica (with chlorite $>$ white mica). Less common components include $<20$ percent glaucophane and glaucophane pseudomorphs, $<10$ percent carbonate, $<7$ percent garnet, $<5$ percent actinolite, $<2$ percent biotite after chlorite, and $<2$ percent epidote + clinozoisite. Accessory minerals include apatite, graphite, ilmenite, magnetite, rutile, sphene, tourmaline (pleochroic colors include blue-green, green, and brown; commonly zoned), and zircon. Magnetic susceptibility is moderate (0.05-2.41, averaging $0.65 \mathrm{x}$ $\left.10^{-3} \mathrm{SI}\right)$. Distinguished from units $€$ sg and $€$ g by its low modal percentages of epidote and clinozoisite.

Op $\epsilon_{m}$ MARBLE (Ordovician to Precambrian) - Fine- to coarse-grained, foliated marble. Light gray weathering, white to gray to light tan colored, often with color banding parallel to foliation. Composed of 85-100 percent carbonate (calcite and rare dolomite) with $<5$ percent each of minor components graphite, white mica, quartz, plagioclase, chlorite, tremolite, and opaque minerals. The marble is cut by scattered calcite \pm quartz \pm iron oxide \pm graphite veins. Magnetic susceptibility is low $\left(0.00-0.27\right.$, averaging $\left.0.02 \times 10^{-3} \mathrm{SI}\right)$.

Op€q QUARTZITE (Ordovician to Precambrian) - Black, fine-grained, foliated graphitic quartzite; locally interlayered with centimeter- to meter-thick, dark gray to black, graphitic schist layers, which constitute less than 10 percent of this quartzite-dominated unit. Modal composition approximately 85-91 percent quartz, 4-10 percent white mica, 2-10 percent graphite, and 0-3 percent chlorite. Analysis of a dark gray, graphitic quartzite from the Big Hurrah mine area of the Solomon C-5 Quadrangle yielded 5.13 percent graphite (Werdon and others, 2005). Magnetic susceptibility is generally low (0.00-3.05, averaging $\left.0.25 \times 10^{-3} \mathrm{SI}\right)$.

Op€sq GRAPHITIC SCHIST AND QUARTZITE (Ordovician to Precambrian) - Composite unit of undifferentiated, fine- to medium-grained, locally interlayered, graphitic schist and quartzite; approximately three-quarters to four-fifths of the unit is schist. Dark gray to black weathering, dark gray to black colored. Schist commonly contains 45-80 percent quartz, 0-30 percent carbonate (generally 10-30 percent), 2-10 percent white mica, 05 percent graphite, 0-3 percent chlorite, and 0-2 percent feldspar (rarely, feldspar up to 25 percent). Contains rare glaucophane replaced by chlorite, plagioclase, quartz, and white mica. Quartzite typically contains 85-93 percent quartz, 1-15 percent white mica, 2-10 percent graphite, 0-10 percent carbonate, and minor accessory rutile. Scattered 0.25-0.5-mm-wide calcite and (or) quartz veinlets cut foliation. Magnetic susceptibility is low (0.00-0.60, averaging $0.09 \times 10^{-3} \mathrm{SI}$ ). Most of the gold-bearing veins within the Big Hurrah creek area are hosted by this unit.

Op€qs QUARTZITE AND SCHIST (Ordovician to Precambrian) - Unit composed of fine-grained, equigranular, poorly foliated, non-graphitic to rarely slightly graphitic, micaceous quartzite and quartz-rich schist. Light to dark gray, blocky weathering. Modal composition 70-90 percent quartz, 3-30 percent white mica, and 0-10 percent calcite; rarely up to 30 percent calcite and up to 35 percent plagioclase. Accessory minerals include opaque minerals, tourmaline, zircon, and rarely, graphite. Locally cut by quartz veins. Magnetic susceptibility is low $\left(0.00-0.36\right.$, averaging $\left.0.14 \times 10^{-3} \mathrm{SI}\right)$. Only found within the Council map area.

Op€s SCHIST (Ordovician to Precambrian) - Medium-grained pelitic schist and lesser calcareous schist. Rarely contains thin, undifferentiated layers of quartzite (Op€q), mafic schist (Op€ms), and impure marble (Op€i). Pelitic schist is light to dark gray colored. Modal composition of the schist is approximately 5-74 percent quartz, 3-57 percent white mica, and 0-25 percent chlorite (with white mica > chlorite). Unit also commonly contains plagioclase (up to 49 percent), glaucophane and glaucophane pseudomorphs (up to 39 percent), chloritoid (up to 35 percent), calcite + dolomite (15-30 percent), and garnet (up to 9 percent). Plagioclase commonly occurs as syn- and post-metamorphic porphyroblasts. Biotite (up to 15 percent) is present as wispy 
crystals finely intergrown with and replacing chlorite. Epidote and clinozoisite are present rarely and generally compose $<2$ percent of the rock. Accessory minerals include apatite, tourmaline (pleochroic colors include green-brown, green, brown, and blue-green; commonly zoned), sphene, graphite, ilmenite, pyrite, rutile, and zircon. Magnetic susceptibility is generally low $\left(0.00-4.44\right.$, averaging $\left.0.19 \times 10^{-3} \mathrm{SI}\right)$.

\section{CASADEPAGA SCHIST}

€g MAFIC SCHIST AND GRANOFELS (Cambrian) - Green, medium- to coarse-grained, massive granofels and foliated mafic schist. Composition varies widely but generally contains epidote + clinozoisite (up to 45 percent), plagioclase (up to 40 percent; occasionally as porphyroblasts), and chlorite (up to 30 percent). Other common components include actinolite (up to 30 percent), barroisite (up to 30 percent), garnet (up to 30 percent), glaucophane and plagioclase + chlorite pseudomorphs of glaucophane (up to 25 percent), quartz (up to 20 percent), carbonate (up to 15 percent), white mica (up to 15 percent; one sample was identified as paragonite by X-ray diffraction), magnetite (up to 13 percent), and biotite after chlorite (up to 10 percent). Accessory minerals include apatite, ilmenite, rutile, and sphene. Secondary minerals include chlorite, quartz, carbonate, and white mica. Carbonate \pm iron oxide veins and lenses locally cut foliation. Trace-element compositions indicate these rocks have arc affinities (Werdon and others, 2005), and major-element compositions suggest basaltic, and sparse andesitic protoliths. It is unclear based on field and compositional evidence whether these represent intrusive or extrusive rocks. Magnetic susceptibility is highly variable (0.03-74, averaging $\left.4.40 \times 10^{-3} \mathrm{SI}\right)$.

Esg METASEDIMENTARY ROCKS AND METAGRAYWACKE (Cambrian) - A composite unit consisting of interlayered metamorphosed greywacke (primarily derived from an andesitic volcanic protolith), pelitic schist, and minor calcareous schist. Forms light greenish-gray weathering, generally planar foliated outcrops that exhibit local recumbent isoclinal folds. Magnetic susceptibility for these different units is highly variable (0.00-54.3, averaging $\left.1.78 \times 10^{-3} \mathrm{SI}\right)$, which may reflect their varying proportions of sphene, rutile, ilmenite, and magnetite.

The pelitic schist is generally light greenish-gray colored and composed of 5-77 percent quartz, 5-55 percent feldspar, 10-40 percent white mica, 0-20 percent epidote + clinozoisite, and 1-18 percent chlorite (with white mica:chlorite greater than 2:1). Minor components of the pelitic schist include glaucophane and glaucophane pseudomorphs, actinolite, biotite, carbonate, chloritoid, garnet, and tourmaline (pleochroic colors include blue-green and rare brown). Accessory minerals include apatite, ilmenite, magnetite, rutile, sphene, and zircon.

The non-pelitic mafic schist and semi-schist are light- to medium grayish-green colored, fine- to mediumgrained, foliated, and either equigranular or porphyroblastic, with plagioclase commonly present as syn- and post-metamorphic porphyroblasts up to $1 \mathrm{~cm}$ in diameter. Modal composition is 10-55 percent plagioclase, 546 percent quartz, and 0-25 percent chlorite. Other common components include barroisite ( $<30$ percent), glaucophane and glaucophane pseudomorphs ( $<25$ percent), epidote + clinozoisite ( $<27$ percent), white mica ( $<25$ percent), and carbonate ( $<15$ percent). Less common minerals include actinolite, biotite, chloritoid, and garnet. Accessory minerals include apatite, ilmenite, magnetite, pyrite, rutile, sphene, tourmaline (pleochroic colors include blue-green and minor brown; commonly zoned), and zircon. Major oxide and petrographic analyses suggest this unit is a meta-graywacke, primarily with andesitic and lesser basaltic protoliths (Werdon and others, 2005).

Calcareous schist is present primarily as centimeter- to meter-thick, discontinuous layers within the other two lithologies; it only occurs as a mappable unit in the southeastern corner of the northern half of the Solomon C-5 Quadrangle. Unit is brownish-gray weathering. Modal composition is 10-40 percent quartz, 10-25 percent carbonate, $10-25$ percent clinozoisite, $0-25$ percent actinolite, $0-20$ percent chlorite, $0-20$ percent glaucophane, 0-20 percent white mica, $0-10$ percent plagioclase, $0-10$ percent garnet, and 0-2 percent biotite. Accessory minerals include apatite, zircon, ilmenite, sphene, and rutile.

$€_{\mathrm{i}} \quad$ IMPURE MARBLE (Cambrian) - Medium-grained, tan, foliated impure marble located in the southeast corner of the northern half of the Solomon C-5 Quadrangle. Gradational into unit $€$ sg. Impurities in the marble include up to 50 percent combined white mica, quartz, and plagioclase. Magnetic susceptibility is low (0.140.18 , averaging $0.16 \times 10^{-3} \mathrm{SI}$ ). 


\section{UNDIFFERENTIATED NOME GROUP}

Op€u UNDIFFERENTIATED NOME GROUP ROCKS (Paleozoic to Precambrian) - Bedrock units of the Nome Group that are covered by glacial material or were not mapped.

\section{SEDIMENTARY AND IGNEOUS ROCKS METAMORPHOSED TO AMPHIBOLITE FACIES}

Pzpeh STAUROLITE SCHIST (Paleozoic to Precambrian) - Fault-bounded wedge of amphibolite facies rocks surrounded by lower grade rocks in the Bendeleben A-4 Quadrangle. White, medium-grained, and equigranular. Modal composition of two samples is 60 percent quartz, 8-22 percent feldspar, 13-20 percent reddish biotite, 0-5 percent staurolite, $0-4$ percent white mica, 2-3 percent magnetite, $0-2$ percent garnet, and trace sillimanite, tourmaline (pleochroic colors are zoned brown, green and gray-blue), apatite, and zircon. High quartz and aluminum content suggests a sedimentary protolith. Magnetic susceptibility is low $(0.08-0.25$, averaging 0.17 $\mathrm{x} 10^{-3} \mathrm{SI}$ ). Unit is coincident with a magnetic high in airborne geophysical data (Burns and others, 2003); perhaps this is due to an underlying, more magnetic unit.

Pzp€a SCHIST AND AMPHIBOLITE (Paleozoic to Precambrian) - Amphibolite facies rocks north of the Bendeleben Fault. Includes pelitic schist and amphibolite. Amphibolite is green, foliated, very fine-grained, and traceelement contents indicate an arc setting for generation of the protolith (Werdon and others, 2005). Magnetic susceptibility of amphibolite measured at a single location is moderate (0.31-0.69, averaging $\left.0.58 \times 10^{-3} \mathrm{SI}\right)$. Schist is dark brown, wavy foliated, coarse grained, and contains biotite, quartz, and feldspar. Likely represents a pelitic protolith. Magnetic susceptibility of schist is low $\left(0.23-0.30\right.$, averaging $\left.0.25 \times 10^{-3} \mathrm{SI}\right)$.

\section{ACKNOWLEDGMENTS}

We would like to thank Alison Till and Laurel Burns for providing reviews of the bedrock geologic maps, Patty Burns (DGGS) and Dick Reger (Reger's Geological Consulting) for their thoughtful reviews of the surficialgeologic maps, and Julia Semprich (University of Alaska Fairbanks) for her assistance with petrographic work. Alison Till (USGS-Anchorage, Alaska) and Jeff Amato (University of New Mexico) provided the U-Pb analysis of detrital zircon from the Solomon Schist. This geologic mapping project was funded primarily through the State's Alaska Airborne Geophysical/Geological Mineral Inventory program. Partial funding was also provided by the U.S. Geological Survey STATEMAP program under STATEMAP award number 04HQAG0061.

\section{REFERENCES CITED}

Amato, J.M., Miller, E.L., Wright, J.E., and McIntosh, W.C., 2003, Dike swarms on Seward Peninsula, Alaska, and their implications for the kinematics of Cretaceous extension in the Bering Strait region: Canadian Journal of Earth Sciences, v. 40, no. 6, p. 865-886.

Armstrong, R.L., Harakal, J.E., Forbes, R.B., Evans, B.W., and Thurston, S.P., 1986, Rb-Sr and K-Ar study of metamorphic rocks of the Seward Peninsula and southern Brooks Range, Alaska, in Evans, B.W., and Brown, E.H., eds., Blueschists and eclogites: Geological Society of America Memoir 164, p. 184-203.

Asher, R.R., 1969, Geological and geochemical study, Solomon C-5 Quadrangle, Seward Peninsula, Alaska: Alaska Division of Geological \& Geophysical Surveys Geologic Report 33, 64 p., 1 sheet at 1:4,000 scale, 1 sheet at 1:63,360 scale.
Barker, Fred, 1994, Some accreted volcanic rocks of Alaska and their elemental abundances, in Plafker, G., and Berg, H.C., eds., Geology of Alaska: Boulder, Colorado, Geological Society of America, The Geology of North America, v. G-1, p. 555-587.

Bundtzen, T.K., Reger, R.D., Laird, G.M., Pinney, D.S., Clautice, K.H., Liss, S.A., and Cruse, G.R., 1994, Preliminary geologic map of the Nome mining district: Alaska Division of Geological \& Geophysical Surveys Public-Data File 94-39, 2 sheets, scale 1:63,360.

Burns, L.E., Fugro Airborne Surveys, and Stevens Exploration Management, 2003, Plot files of the airborne geophysical survey data of the Council area, Seward Peninsula, Alaska: Alaska Division of Geological \& Geophysical Surveys Geophysical Report 2003-1, 1 CD-ROM.

Burns, L.E., Fugro Airborne Surveys, and Stevens Exploration Management Corp., 2005, Line, gridded, and vector data, and selected plot files of the airborne geophysical survey data of the Nome mining district, Seward Peninsula, Alaska: Alaska Division of Geological \& Geophysical Surveys Geophysical Report 2004-6, 1 CD-ROM.

Buxton, C.L., 1990, Geology and pre-metamorphic evolution of the Nome Group blueschist terrane, Horton Creek area, Seward Peninsula, Alaska: Seattle, Washington, University of Washington, unpublished Master's thesis, 115 p., 2 sheets, scale 1:36,680.

Collier, A.J., Hess, F.L., Smith, P.S., and Brooks, A.H., 1908, The gold placers of parts of Seward Peninsula, Alaska, including the Nome, Council, Kougarok, Port Clarence, and Goodhope precincts: U.S. Geological Survey Bulletin 328, 343 p., 4 sheets, scale 1:250,000.

Faure, Gunter, 1986, Principles of Isotope Geology, 2nd edition: New York, Wiley and Sons, 589 p. 
Forbes, R.B., Evans, B.W., and Thurston, S.P., 1984, Regional progressive high-pressure metamorphism, Seward Peninsula, Alaska: Journal of Metamorphic Geology, v. 2, p. 43-54.

Ford, R.C., 1993, Geology, geochemistry, and age of gold lodes at Bluff and Mt. Distin, Seward Peninsula, Alaska: Golden, Colorado, Colorado School of Mines, unpublished Ph.D. dissertation, 302 p.

Ford, R.C., and Snee, L.W., 1996, ${ }^{40} \mathrm{Ar} /{ }^{39} \mathrm{Ar}$ thermo-chronology of white mica from the Nome district, Alaska: The first ages of lode sources to placer gold deposits in the Seward Peninsula: Economic Geology, v. 91, no. 1, p. 213-220.

Gaccetta, J.D., and Church, S.E., 1989, Lead isotope database for sulfide occurrences from Alaska, December, 1989: U.S. Geological Survey Open-File Report 89-688, $60 \mathrm{p}$.

Kaufman, D.S., 1986, Surficial geologic map of the Solomon, Bendeleben, and southern part of the Kotzebue quadrangles, western Alaska: U.S. Geological Survey Miscellaneous Field Studies Map MF-1838-A, 1 sheet, scale $1: 250,000$.

Kaufman, D.S., and Hopkins, D.M., 1986, Glacial history of the Seward Peninsula, in Hamilton, T.D., Reed, K.M., and Thorson, R.M., eds., Glaciation in Alaska - The geologic record: Alaska Geological Society, p. 51-78.

Kaufman, D.S., Walter, R.C., Brigham-Grette, J., and Hopkins, D.M., 1991, Middle Pleistocene age of the Nome River glaciation, northwestern Alaska: Quaternary Research, v. 36, p. 277-293.

Meschede, Martin, 1986, A method of discriminating between different types of mid-ocean ridge basalts and continental tholeiites with the Nb-Zr-Y diagram: Chemical Geology, v. 56, p. 207-218.

Miller, T.P., 1972, Potassium-rich alkaline intrusive rocks of western Alaska: Geological Society of America Bulletin, v. 83, no. 7, p. 2,111-2,128.

Moffit, F.H., 1913, Geology of the Nome and Grand Central quadrangles, Alaska: U.S. Geological Survey Bulletin 533, 140 p.

Mutschler, F.E., 1981, compiler, PETROS Igneous Petrology Databank, version 6.1, U.S. Department of Commerce, National Geophysical Data Center Data Set \# 0030, 9 megabyte digital file.

Patrick, B.E., and McClelland, W.C., 1995, Late Proterozoic granitic magmatism on Seward Peninsula and a Barentian origin for Arctic Alaska-Chukotka: Geology, v. 23, no. 1, p. 81-84.
Pearce, J.A., and Cann, J.R., 1973, Tectonic setting of basic volcanic rocks determined using trace element analyses: Earth and Planetary Science Letters, v. 19, p. 290-300.

Read, J.J., and Meinert, L.D., 1986, Gold-bearing quartz vein mineralization at the Big Hurrah mine, Seward Peninsula, Alaska: Economic Geology, v. 81, p. 1,760-1,774.

Rollinson, H.R., 1993, Using Geochemical Data: Evaluation, Presentation, Interpretation: New York, John Wiley and Sons, Inc., 352 p.

Smith, P.S., 1910, Geology and mineral resources of the Solomon and Casadepaga quadrangles, Seward Peninsula, Alaska: U.S. Geological Survey Bulletin 433, 234 p.

Smith, P.S., and Eakin, H.M., 1911, A geologic reconnaissance in southeastern Seward Peninsula and the Norton Bay-Nulato region. Alaska: U.S. Geological Survey Bulletin 449, 146 p., 3 sheets, scale 1:250,000.

Thurston, S.P., 1985, Structure, petrology, and metamorphic history of the Nome Group blueschist terrane, Salmon Lake area, Seward Peninsula, Alaska: Geological Society of America Bulletin, v. 96, p. 600-617.

Till, A.B., and Dumoulin, J.A., 1994, Seward Peninsula: the Seward and York terranes, in Plafker, G., and Berg, H.C., eds., Geology of Alaska: Boulder, Colorado, Geological Society of America, The Geology of North America, v. G-1, p. 141-152.

Till, A.B., Dumoulin, J.A., Gamble, B.M., Kaufman, D.S., and Carroll, P.I., 1986, Preliminary geologic map and fossil data, Solomon, Bendeleben, and southern Kotzebue quadrangles, Seward Peninsula, Alaska: U.S. Geological Survey Open-File Report 86-276, 71 p., 3 plates, scale $1: 250,000$.

Werdon, M.B., Burns, L.E., Stevens, D.S.P., and Till, A.B., 2003, DGGS Airborne Geophysical/ Geological Mineral Inventory Program: Preliminary geophysical and geological interpretations of the Solomon-Council area, Seward Peninsula, Alaska: [abstr.] Alaska Miners Association Annual Convention, Nov. 3-8, 2003, p. 9-11.

Werdon, M.B., Szumigala, D.J., Newberry, R.J., Athey, J.E., and Hicks, S.A., 2005, Major-oxide, minor-oxide, traceelement, geochemical, and non-carbonate carbon data from rocks collected in the Solomon, Bendeleben, and Nome Quadrangles, Seward Peninsula, Alaska in 2003 and 2004: Alaska Division of Geological \& Geophysical Surveys Raw Data File 2005-2, 46 p.

Young, L.E., 1995, Possible thrust windows on the central Seward Peninsula, in Combellick, R.A., and Tannian, Fran, eds., Short Notes on Alaska Geology 1995: Alaska Division of Geological \& Geophysical Surveys Professional Report 117, p. 97-113. 


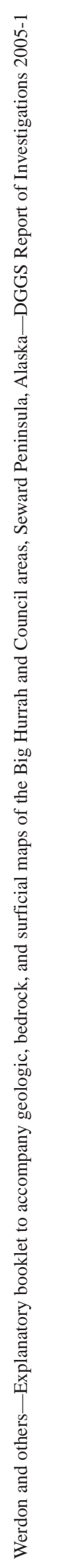

